\title{
Molecular phylogeny of Anthelidae and other bombycoid taxa (Lepidoptera: Bombycoidea)
}

\author{
A N D R A S Z W I C K ${ }^{1,2}$ \\ ${ }^{1}$ CSIRO Entomology, Canberra, Australian Capital Territory, Australia and ${ }^{2}$ School of Botany and Zoology, \\ The Australian National University, Canberra, Australian Capital Territory, Australia
}

\begin{abstract}
Based on DNA sequences of the fusion protein carbamoylphosphate synthetase/aspartate transcarbamylase/dihydroorotase (CAD; $680 \mathrm{bp}$ ) and elongation factor- $1 \alpha(\mathrm{Ef}-1 \alpha ; 1240 \mathrm{bp})$; the first molecular phylogeny of the moth family Anthelidae and its placement within the Bombycoidea sensu Brock (1971) (= bombycoid complex sensu Minet, 1994) is proposed. The results strongly support the monophyly of the family Anthelidae and its subfamilies Munychryiinae and Anthelinae, but demonstrate the vast polyphyly of its main genus Anthela Walker, 1855. The proposed phylogeny suggests that grass feeding, as apparent from some pest records, probably is an ancestral trait within the subfamily Anthelinae. Evolutionary relationships of the family Anthelidae and of most parts of the Bombycoidea remain obscure. However, the results contradict many of the widely accepted phylogenetic hypotheses within the Bombycoidea proposed by Minet (1994: Entomologica scandinavica, 25, 63-88). The Brahmaeidae are paraphyletic relative to the Lemoniidae (syn.nov.), and the current concept of Bombycidae is polyphyletic, with the bombycid subfamily Apatelodinae being part of a monophylum comprising Brahmaeidae / Lemoniidae, Eupterotidae and Apatelodidae (stat.rev.).
\end{abstract}

\section{Introduction}

The Anthelidae form a small family of moths restricted to Australia and New Guinea. At present the family comprises 74 species in eight genera described from Australia (Edwards \& Fairey, 1996) and 20 species from New Guinea in one endemic genus and one genus shared with Australia. Numerous distinct species have already been identified as undescribed in museum collections, in particular in the very extensive Australian National Insect Collection (ANIC). Further undescribed species are expected to exist, as many of these moths, which are widely distributed throughout the whole of Australia, are rather inconspicuous.

The large genus Anthela Walker, $1855^{1}$ comprises $80 \%$ of all described Anthelidae and is unlikely to be monophyletic. The current unsatisfactory knowledge of its taxonomy is

Correspondence: Andreas Zwick, Center for Biosystems Research, University of Maryland Biotechnology Institute, 5142 Plant Sciences Building, College Park, MD 20742, U.S.A. E-mail: andreaszwick@web.de

${ }^{1}$ For taxa that have been sampled in this study, taxonomic names with their author and year combinations are listed in the Appendix. symptomatic of the current classification of all Anthelidae, which is based on superficial differences or similarities only and merely separates 'odd' taxa from the principal genus Anthela. No hypothesis on the phylogeny of Anthelidae has been published to date. Similarly, the systematic position of the Anthelidae within the poorly defined Bombycoidea ${ }^{2}$ is uncertain. Numerous publications relate to systematics within bombycoid families, but only few hypotheses on relationships (most are, at best, phenetic) between bombycoid families are based on phylogenetic studies. These particular publications are Brock (1971), Kuznetzov \&

\footnotetext{
${ }^{2}$ The superfamily name Bombycoidea is not used in the sense of Minet (1994), but in the more inclusive sense of Brock (1971), which is equivalent to the 'bombycoid complex' sensu Minet (1994). This preference is made because molecular (Regier et al., 2008) and morphological characters (Zwick, in prep.) strongly contradict the hypothesis of monophyly of the Bombycoidea sensu Minet (1994). Fänger (1999) introduced the name 'Bombycomorpha' as a replacement for 'bombycoid complex' sensu Minet (1994). However, this informal name is not used, because it is redundant and can be confused with the African lasiocampid genus Bombycomorpha Felder, 1874.
} 
Stekolnikov (1985, 2001), Scott (1986), Minet (1986, 1991, 1994), Lemaire \& Minet (1998) (based on Minet, 1994), Niculescu (1988), and Stekolnikov \& Zolotukhin (2002). All these studies are based on morphology, none uses softwarebased cladistic analyses, and those based on Hennigian principles lack the crucial discussions of the assumed character polarity and weights. The only software-based cladistic analyses that include some bombycoid family relationships (Weller \& Pashley, 1995; Regier et al., 1998) were based on DNA sequences, but have insufficient sampling of bombycoid taxa (four and 13 species, respectively) and statistically unsupported results at the family level.

Of all the aforementioned publications, only the morphologybased studies of Brock (1971), Minet (1991, 1994) and Lemaire \& Minet (1998) actually examine Anthelidae, and the studies by Minet are currently the most comprehensive and most widely accepted. Based on five proposed synapomorphies, Minet $(1991,1994)$ hypothesized a sistergroup relationship between Anthelidae and Lasiocampidae, placed together in a superfamily of their own, the Lasiocampoidea. This superfamily, the monotypic Mimallonoidea and the Bombycoidea sensu stricto constitute the 'bombycoid complex' sensu Minet (1994). Based on muscles of male genital structures, Kuznetzov \& Stekolnikov (2001) added Lemoniidae, Eupterotidae and Apatelodidae to the superfamily Lasiocampoidea, but, apparently in the absence of study material, accepted the sister-group relationship between Lasiocampidae and Anthelidae proposed by Minet (1991). The inclusion of Lemoniidae in Lasiocampoidea was supported by Stekolnikov \& Zolotukhin (2002).

The Bombycoidea include the well-known families Sphingidae and Saturniidae as well as several economically and, as model organisms, scientifically very important species, for example Bombyx mori (Bombycidae), Manduca sexta (Sphingidae) and Antheraea spp. (Saturniidae). The number of studies published on these organisms is in stark contrast to the poorly understood relationships between (or even within) bombycoid families, and this contrast is reflected most clearly by DNA sequences deposited in GenBank. At the time of writing (middle of 2007), GenBank holds almost half a million entries of Bombyx mori and B. mandarina sequences, but only a single sequence of one of the other 350 bombycid species (species number according to Lemaire \& Minet, 1998). Of the remaining 11 families of the Bombycoidea, only Saturniidae (7800), Sphingidae (5000) and Lasiocampidae (88) have noteworthy numbers of sequence entries, with the bulk of the sequences being expressed sequence tags (ESTs) of a few molecular model species and cytochrome oxidase I (COI) barcodes. By contrast, less than five or no sequences at all (Anthelidae, Eupterotidae, Carthaeidae and Mirinidae) are available from GenBank for other bombycoid families. Clearly, the molecular phylogeny of the Bombycoidea is still in its infancy, despite the significance and popularity of the group.

This paper provides a first hypothesis of anthelid phylogeny and of the placement of the family Anthelidae within the Bombycoidea, based on cladistic analyses of molecular data. Ultimately, this phylogenetic hypothesis contributes to a natural, stable generic classification of the Anthelidae.

\section{Materials and methods}

Taxon and gene sampling

Representatives of all bombycoid families except Mirinidae and of as many subfamilies as available were sequenced. In an attempt to increase the density of sampling at higher taxonomic levels, particular efforts were made to include monotypic taxa (e.g. Carthaeidae, Endromidae, Agliinae), taxa known to possess many or, for a (sub)family, unusual plesiomorphic characteristics (e.g. Chionopsyche, Ganisa, Aglia) and poorly known taxa (e.g. Dactyloceras, Sabalia, Gastridiota, Panacela). Within the Anthelidae, taxa were sampled much more broadly to permit the detection of non-monophyly of genera and to provide a representative basis for subsequent delimitation of genera (Zwick, in prep.). Because $80 \%$ of all anthelid species have been described indiscriminately or placed in the genus Anthela, species groups were identified for all described and undescribed species in the ANIC on the basis of male genital structures. Representatives of almost all identified species groups could be obtained for sequencing, except for an undescribed, monotypic munychryiine genus from Western Australia, the antheline species group of Anthela neurospasta/ A. achromata and Pterolocera isogama. A comprehensive list of all sampled species with author and year, voucher number, GenBank accession numbers and locality data is given in Appendix 1.

To choose within the limits of primer availability the most suitable gene for the reconstruction of anthelid phylogeny, several genes commonly used in phylogenetic studies of Lepidoptera were sequenced and preliminarily analysed for a 'test set' of ten anthelid and lasiocampid species (data not shown). Of these, the ribosomal genes 18S, 12S and 28S (D2/D3 region) are considered unsuitable, because stem areas of their secondary structure are too constant, whereas loop areas are very variable in length and difficult to align for phylogenetic analyses. The protein coding genes cytochrome oxidase I and II (COI and COII), and elongation factor- $1 \alpha$ (EF-1 $\alpha)$ are similarly constant in the first and second codon positions, but the variable third codon positions of EF-1 $\alpha$ seem less saturated than the third codon positions of COI and COII. Consequently, a 1240-bp fragment of the commonly sequenced gene EF- $1 \alpha$ was chosen as one molecular marker. To obtain an additional, independent set of data, a second gene with potentially more variation in the first and second codon positions was chosen from the literature. The carbamoylphosphate synthetase (CPS) domain of the fusion protein CAD (carbamoylphosphate synthetase/aspartate transcarbamylase/dihydroorotase) has been used in a study of dipteran phylogeny by Moulton \& Wiegmann (2004), but not yet in lepidopteran phylogeny. Based on their descriptions, a region with high 
non-synonymous divergence and low homoplasy in Diptera was chosen for the sequencing of Lepidoptera, namely, part of their fragment \#4.

\section{$D N A$ sequencing}

Whole live specimens, preferably male imagines for reliable identification, were fixed in $96 \%$ or absolute ethanol and stored at $-20^{\circ} \mathrm{C}$. Voucher specimens (Appendix 1) are stored at the Australian National Insect Collection, Canberra (ANIC). Sequences were generated in two laboratories over time, which resulted in two methods being used for most tasks. All extracts of genomic nucleic acids were made from thoracic muscles or, in a few cases, first instar larvae. Initially, nucleic acids were obtained by manually grinding the samples and applying a salt extraction method described in Sunnucks \& Hales (1996). Later, a commercial extraction kit (UltraClean Tissue DNA Isolation Kit, Mo Bio Laboratories, Carlsbad, CA) was used instead, utilizing a bead solution with a homogenizer (FastPrep FP120, Qbiogene, Morgan Irvine, CA) and silica spin filter to extract DNA.

The CAD primers of Moulton \& Wiegmann (2004) are highly degenerate, and the primer pair used in this study for bombycoid taxa (806F and 1124R) resulted in multiple fragments, not only during polymerase chain reaction (PCR) amplification, but, more significantly, during sequencing reaction from gel-excised PCR products. Based on a few bombycoid CAD sequences obtained with these primers, a more specific reverse primer (1057R_Bom: CTC Awr TCA TAA TCw GTr CTh AC) was designed that works well in combination with the original forward primer (806F). Subsequently, CAD primers optimized for Lepidoptera were made available by Regier (2007), and the original forward primer $806 \mathrm{~F}$ was replaced with the more specific $791 \mathrm{~F}$ to sequence additional taxa. This primer also is highly degenerate, but the appending of non-degenerate M13REV and M13(-21) tails (Regier \& Shi, 2005) to 791F and 1057R Bom, respectively, enabled reliable and efficient (re-)amplification and sequencing of gel-excised PCR products. Despite its name, $791 \mathrm{~F}$ is located downstream of $806 \mathrm{~F}$, and, consequently, CAD sequence fragments used in this study are either 680 bp (806F/1057R_Bom) or 598 bp (791F/ $1057 \mathrm{R}$ B Bom) long. The $1240 \mathrm{bp}$ of EF-1 $\alpha$ were sequenced in three overlapping fragments, using the primer pairs M3/ rcM51.1 (540 bp), M46.1/M52.6 (353 bp) and M51.9/rcM4 (516 bp). See Supplementary Material Table ST1 for primer sequences and sources.

DNA amplifications were carried out in $25.5 \mu \mathrm{L}$ volumes, containing $14 \mu \mathrm{L}$ of MQ water, $3 \mu \mathrm{L}$ of $\mathrm{MgCl}_{2}(25 \mathrm{mM})$, $2.5 \mu \mathrm{L}$ of PCR buffer $(10 \times), 2 \mu \mathrm{L}$ of dNTPs $(2 \mathrm{mM}), 0.5$ $\mu \mathrm{L}$ of each forward and reverse primer $(10 \mu \mathrm{M}), 1 \mu \mathrm{L}$ of DNA polymerase $(0.75 \mathrm{U} / \mu \mathrm{L}$; Taq, Qiagen or Taq-ti, Fisher Biotech Australia, Wembley, WA, Australia) and $2 \mu \mathrm{L}$ of DNA template. All fragments were amplified with a general touch-down program, whereby the annealing temperature was reduced gradually over a few cycles from $65^{\circ} \mathrm{C}$ to $40^{\circ} \mathrm{C}$, at which 35 amplification cycles were carried out (see Supplementary Material Table ST2). PCR products were electrophoresed in $1 \%$ agarose gel, excised from it and recovered with a silica spin filter (UltraClean GelSpin DNA Purification Kit, Mo Bio Laboratories). In the case of faint bands, the PCR products were reamplified with the M13REV/M13(-21) primers and purified by gel extraction (same conditions and steps as for all other primers).

The majority of sequences were generated with an ABI 3100 Genetic Analyzer (Applied Biosystems, Foster City, CA) automated cycle sequencer, using the BigDye 3.1 mixture. All other sequences originate from a CEQ 8000 Genetic Analysis System (Beckman Coulter, Fullerton, CA), using the corresponding Dye Terminator Cycle Sequencing mixture. For all fragments the forward as well as the reverse strand were sequenced. All resulting chromatograms were processed with the software package PHRED/PHRAP/CONSED (Ewing \& Green, 1998; Ewing et al., 1998; Gordon et al., 1998). Chromatograms were reanalysed with the basecaller PHRED (version 0.020425.c) to generate alternative sequences with quality values for every basecall. Contigs of all reads were assembled with PHRAP (version 0.990329), using the quality values generated by PHRED as guidance and thereby eliminating the need to cut off stretches of low-quality sequence (ends) prior to assembly. All contigs were checked manually against their chromatograms in the graphical contig editor CONSED (version 15.1), using ABI or Beckman Coulter as well as PHRED basecalls.

\section{Phylogenetic analyses}

Sequences were aligned with the multiple alignment program ClustalX (version 1.83; Thompson et al., 1997), using default parameters. The alignment of the two protein coding genes was straightforward, and all alignments were checked visually with the program SEAVIEW (Galtier et al., 1996). The aligned CAD and EF-1 $\alpha$ datasets were analysed separately as well as combined with the phenomenological method of maximum parsimony (MP) and the processdependent methods of maximum likelihood (ML) and Bayesian inference (BI).

MP analyses were carried out with PAUP* (version 4.0B10; Swofford, 2002) on a restricted dataset, containing only 49 taxa for which sequences of both CAD and EF-1 $\alpha$ were available. Characters were analysed unweighted (with an implied equal weight) as well as with arbitrary differential weights by codon position to assess the impact of potentially saturated third codon positions on the analyses. The sets of weights by codon position were 1-1-1 (unweighted), 2-3-1, 5-5-1, 10-10-1 and 1-1-0 (third codon positions excluded). In all analyses, a heuristic search with branch swapping by tree-bisection-reconnection (TBR), random sequence additions and 10000 replicates was used. Resulting trees were rooted by outgroup addition of Ochrogaster lunifer (Noctuoidea: Notodontidae); the use of the additional outgroup taxa Oenosandra boisduvalii Newman, 1856 (Noctuoidea: Oenosandridae) and 
Aglaopus pyrrhata (Walker, 1866) (Thyridoidea: Thyrididae) did not change the ingroup topology (sequence data incomplete, results not shown). Bootstrap percentages were calculated in PAUP* from 1000 pseudo-replicates with ten replicates each. Partitioned Bremer support values (PBS; Baker et al., 1998) for partitions by codon position and gene were calculated by the program TREEROT (version 2b; Sorenson, 1999) for strict consensus trees resulting from the MP analyses.

Based on the hierarchical likelihood ratio tests (hLRT) and Akaike information criterion (AIC) as implemented in the program ModelTest (version 3.7; Posada \& Crandall, 1998), the GTR + I + G model was chosen as the best-fitting model for all process-dependent analyses. The ML analyses were run with GARLI (version 0.951; Zwickl, 2006) on the full datasets, including species lacking either CAD or EF-1 $\alpha$. Each analysis was replicated 100 times and bootstrap percentages were calculated from 1000 pseudo-replicates.

Bayesian analyses were carried out with the software MrBAyes (version 3.1.2; Huelsenbeck \& Ronquist, 2001; Ronquist \& Huelsenbeck, 2003) on the full datasets that include all taxa and all codon positions. To assess the influence of potentially saturated third codon positions, a combined analysis excluding third codon positions was also run. Datasets were partitioned by codon positions and by genes, where applicable. Because first and second codon positions are not very variable and each is likely to evolve similarly in CAD and EF- $1 \alpha$, an additional combined analysis was run with the data partitioned into first, second, third CAD and third EF-1 $\alpha$ codon positions to reduce the negative effects of the paucity of variation on the analysis. A partition into first and second codon positions combining the codon positions of CAD and EF- $1 \alpha$ was also used for the combined analysis, excluding third codon positions. Default values were used for the prior probability distribution of the parameters of the likelihood model $($ GTR + I + G), with the exception of the rate multipliers of the partitions, which were specified to be variable. For all partitions the gamma shape parameter, proportion of invariable sites, character state frequencies, and substitution rates of the GTR + I + G model were unlinked. The Markov chain Monte Carlo analysis was run for 5000000 cycles, and samples were take every 100 cycles. Each analysis consisted of two simultaneous, independent runs, and each analysis was run three times. The resulting six independent runs were pooled for the generation of a strict consensus tree. This strict consensus tree includes only trees that were sampled after not only loglikelihood values, but all parameters had converged, which was checked with TRACER (version 1.3; Rambaut \& Drummond, 2003) and typically resulted in discarding the first $25 \%$ of all samples.

The phylogram derived by Bayesian inference of the combined CAD and EF-1 $\alpha$ data was used to map reliable host records. Mapping was carried out with the Ancestral State Reconstruction Packages of the software MESQUiTE (version 2.0; Maddison \& Maddison, 2007), with ancestral host usage being reconstructed on the basis of parsimony.

\section{Results}

\section{Sequence data}

The sequence fragments of both genes, CAD and EF-1 $\alpha$, were sequenced successfully for all Anthelidae (32 species) other than Chelepteryx collesi (no EF-1 $\alpha$ ) and for the outgroup taxon Ochrogaster lunifer (Noctuoidea: Notodontidae). However, sequences of both genes are available for only a subset of other bombycoid taxa (17 out of 33 species) and the outgroup, because a preliminary analysis of EF-1 $\alpha$ sequences indicated that EF- $1 \alpha$ generally is not informative at the bombycoid family level. Hence, no attempt was made to obtain EF-1 $\alpha$ sequences for all representatives of families other than the Anthelidae. Furthermore, EF-1 $\alpha$ sequences of Lemonia dumi (Lemoniidae) and Acanthobrahmaea europaea (Brahmaeidae) were obtained from GenBank, and no CAD sequences are available for these taxa.

Of the maximal $680 \mathrm{bp}$ of CAD, 200 sites (29.4\%) within the Anthelidae are parsimony-informative, as are 291 sites $(42.8 \%)$ within all bombycoid taxa (including Anthelidae, but excluding those 20 taxa that lack either CAD or EF-1 $\alpha$ ). Broken up into individual codon positions, their contribution to the total number of parsimony-informative sites is very disproportionate. $71.8 \%(93.4 \%)$ of third codon positions of $\mathrm{CAD}$ are parsimony-informative within the Anthelidae (Bombycoidea), whereas only 11.5\% (23.5\%) and $4.9 \%(11.5 \%)$ of first and second codon positions, respectively, are parsimony-informative. Likewise, of the 1240 bp of EF-1 $\alpha, 245$ sites (19.8\%) within the Anthelidae are parsimony-informative, as are 358 sites $(28.9 \%)$ within all bombycoid taxa. $55.6 \%(79.7 \%)$ of third codon positions of EF-1 $\alpha$ are parsimony-informative within the Anthelidae (Bombycoidea), whereas a mere $2.7 \%(5.1 \%)$ and $1.0 \%$ $(1.7 \%)$ of first and second codon positions, respectively, are parsimony-informative. The proportion of parsimonyinformative sites is illustrated in Fig. 1 for each codon position, highlighting the large differences between codon positions as well as between the two gene fragments.

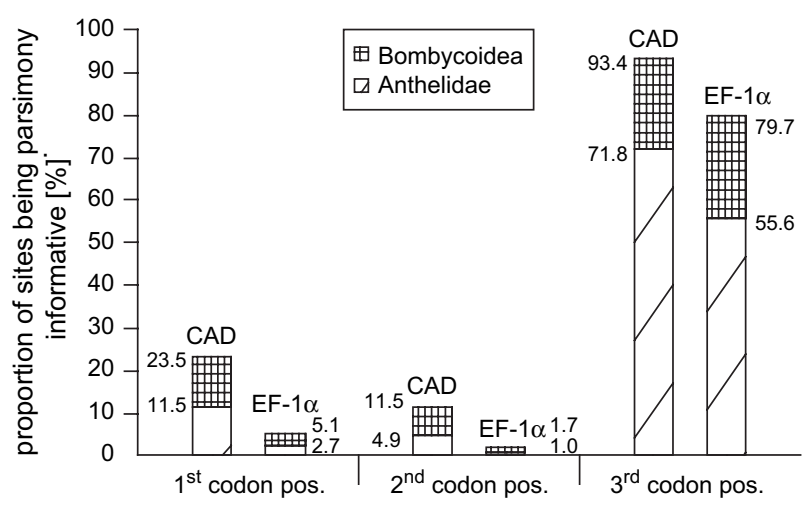

Fig. 1. Comparison of the proportion of parsimony-informative sites of the three codon positions of CAD and EF-1 $\alpha$ for the Anthelidae and for the Bombycoidea (incl. Anthelidae). 
The information content of molecular data, like that of morphological data, depends not only on the quantity of parsimony-informative characters, but also on their quality in a phylogenetic sense. Of all the characters used in this study, only the third codon positions of EF- $1 \alpha$ have a statistically significant heterogeneity in base composition across taxa that might influence phylogenetic analyses negatively $\left(\chi^{2}\right.$-test implemented in PAUP calculates $P=0$ ). This bias of third codon positions of EF- $1 \alpha$ is extremely strong within the Anthelidae and all bombycoid taxa, but the origin of this bias could not be pinpointed to individual sequences.

Furthermore, phylogenetic information becomes eroded over time by multiple substitutions of bases at one site ('saturation' of a site), which erases any older phylogenetic information present at that site. Such multiple substitutions cannot be observed directly, but their occurrence can be inferred from the transition/transversion ratio $(\mathrm{Ti} / \mathrm{Tv})$ of substitutions. The rates at which transitions and transversions occur are not equal, with transitions occurring more frequently than transversions. Because multiple substitutions cannot be identified as such, the ratio of transitions to transversions ( $\mathrm{Ti} / \mathrm{Tv}$ ratio) appears to decrease over time to a level at which it does not change any further. Hence, convergence of the calculated $\mathrm{Ti} / \mathrm{Tv}$ ratio over time
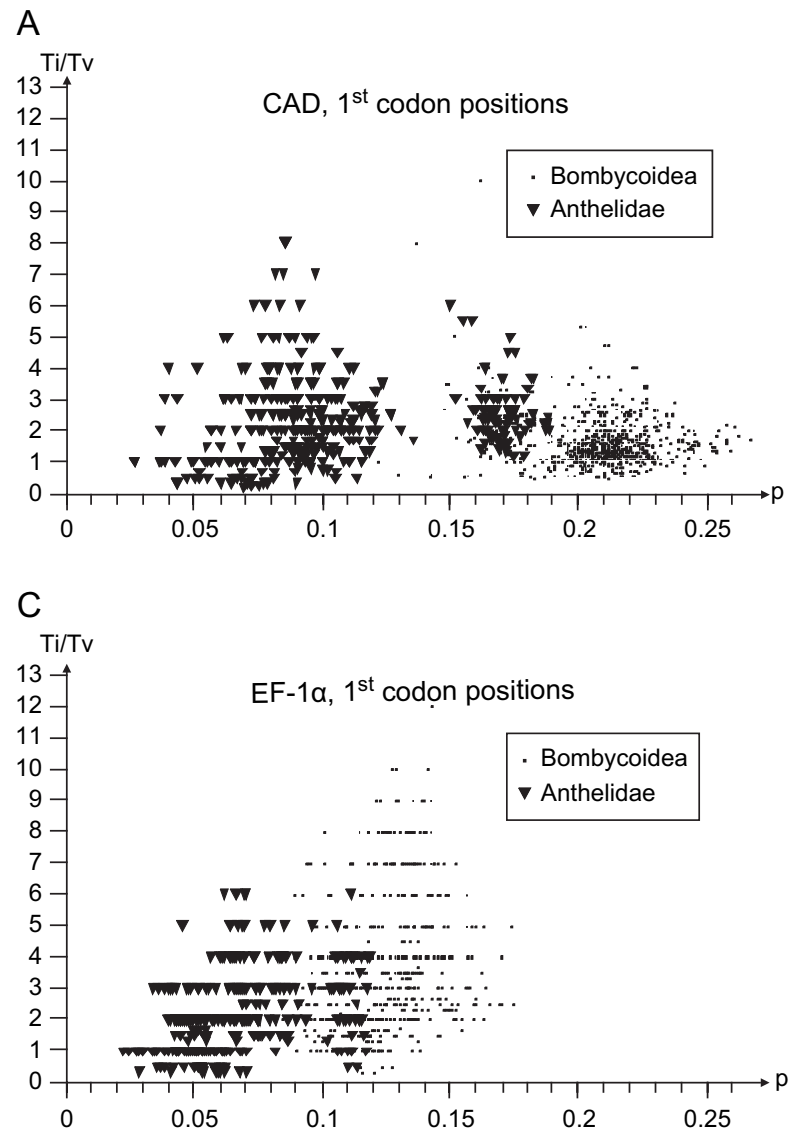

indicates saturation. As different taxa diverged from each other at different times, plotting sequence $\mathrm{Ti} / \mathrm{TV}$ ratios of different taxon pairs against the pairwise distances of each of these taxon pairs gives a rough indication of the degree of sequence saturation. In this study, such saturation plots indicate that first codon positions of CAD (Fig. 2A) and EF-1 $\alpha$ (Fig. 2C) are not saturated within the Anthelidae, but in CAD start to become saturated for older splits between bombycoid taxa. By contrast, the third codon positions of CAD (Fig. 2B) and EF-1 $\alpha$ (Fig. 2D) start to become saturated for older splits within the Anthelinae, and are saturated for splits between the anthelid subfamilies Anthelinae and Munychryiinae as well as for older splits between bombycoid taxa. The second codon positions of both genes are too constant to assess saturation with this method, but are probably at least no more saturated than the more variable, non-saturated first codon positions.

\section{Phylogenetic analyses}

Like morphological characters, molecular characters are not factual data: they are only hypotheses of homology based on the identity of individual bases at each site as

\section{B}
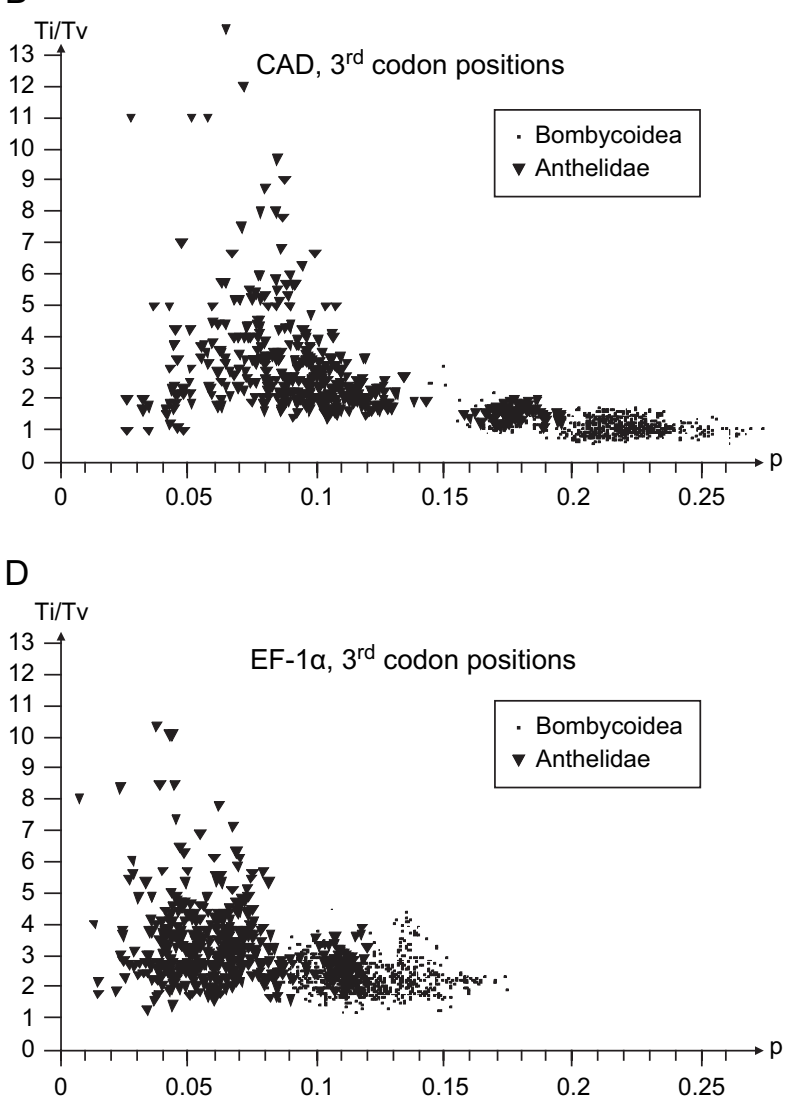

Fig. 2. Saturation plots, plotting transition to transversion ratios (Ti/Tv) against uncorrected pairwise distances (p): (A) first codon positions of CAD; (B) third codon positions of CAD; (C) first codon positions of EF-1 $\alpha$; (D) third codon positions of EF-1 $\alpha$. 
determined by the alignment of sequences (Wägele, 2001). The crucial alignment of sequences was straightforward for both CAD and EF-1 $\alpha$, because neither of the gene fragments contains introns or indels in the Bombycoidea sequenced (unlike other CAD fragments in Diptera - see Moulton \& Wiegmann, 2004).

The aligned sequences of CAD and EF-1 $\alpha$ were analysed separately and combined with the phenomenological method of MP and the process-dependent methods of ML and BI. For all methods of analysis, the cladograms of individually analysed genes largely are compatible with the cladograms of the corresponding combined gene analyses, differing only in a few nodes with little or no statistical support. Hence, only cladograms of the combined gene analyses are presented in Figs 3-5. Branches in bold are present in both of the independent analyses of individual genes. Despite phenomenological and process-dependent methods being fundamentally different, the resulting cladograms of the combined gene analyses are largely congruent and differ in no statistically supported nodes (Figs 3-5). In the case of the ML and BI analyses, the resulting phylograms (Figs 4, 5) have almost identical topologies and differ only marginally in branch lengths, statistical support values and the resolution of one unsupported node.

In the Anthelidae, smaller groups within and across genera are strongly supported as monophyletic by all analyses of both genes. However, relationships between many of these well-supported monophyla are less well supported or even unresolved. By contrast, the monophyly of the even more inclusive subfamilies Anthelinae and Munychryiinae as well as that of the entire family Anthelidae are strongly supported by all analyses of both genes.

Within the limits of insufficient sampling, the monophyly of almost all other bombycoid families and of groups within these families is recovered and typically well supported by $\mathrm{CAD}$, but less so by EF-1 $\alpha$, in particular in the MP analysis. The only exception is the family Bombycidae sensu Minet (1994), which is polyphyletic. This family is incompletely represented in this study by its subfamilies Bombycinae and Apatelodinae, but both subfamilies are always separately included in different, more inclusive monophyla by all analyses of both genes (see below).

By contrast, relationships between bombycoid families generally are not statistically supported and vary between genes. This is true also for the family Anthelidae, for which the sister-group relationship differs between genes and methods of analysis and is never supported statistically. Exceptions to this tendency are the families Lemoniidae and Brahmaeidae, which universally form a statistically wellsupported monophylum in all analyses of both genes. Furthermore, all analyses of both genes support the Eupterotidae as being the sister group of the Lemoniidae + Brahmaeidae, and most analyses of both genes place the Apatelodinae as the sister group of Lemoniidae + Brahmaeidae + Eupterotidae.

Regarding the monophyly of the Bombycoidea sensu Brock (1971), the Bombycoidea sensu Minet (1994), the Mimallonoidea and the Lasiocampoidea sensu Minet
(1994), the results of the analyses are inconclusive. The outgroup family Notodontidae (Noctuoidea) is always placed in a polytomy with one or more bombycoid families, and any groupings at the superfamily level are neither supported statistically nor consistent between analyses.

The phylograms and statistical support values in Figs 3-5 are based on equal character weights and are the analyses generally referred to in the text. However, to test for the influence of saturation in predominantly third codon positions, MP analyses of the data were carried out with equally, as well as differentially, weighted codon positions, to the extent of excluding third codon positions (results not shown). These arbitrary differential weighting schemes (2: $3: 1,5: 5: 1,10: 10: 1,1: 1: 0)$ do not result in any wellsupported monophyla different from those generated by the analyses of unweighted characters. Instead, support values and resolution decrease with decreasing relative weight of third codon positions, and these support values are included in Fig. 3. Likewise, BI analysis of the combined CAD and EF-1 $\alpha$ sequences excluding third codon positions does not result in any statistically supported relationships between bombycoid families, and many of the more recent splits are unresolved. Hardly any monophyla are supported by first and second codon positions of EF- $1 \alpha$ alone, and the phylogram topology of the combined CAD and EF-1 $\alpha$ analysis (see Supplementary Material SM1) is driven largely by the CAD data. This loss of resolution accords with the paucity of parsimony-informative characters in first and second codon positions of both genes, and of EF- $1 \alpha$ in particular.

\section{Discussion}

Comparing the phylograms and statistical data of the two genes, CAD clearly outperforms EF- $1 \alpha$ in terms of phylogenetic usefulness. Although the CAD data are only half the size of the EF-1 $\alpha$ sequences, they are largely driving the analyses, in particular for older splits. Taking differences in sequence length and number into account, CAD provides more than four times as many parsimony-informative characters in first codon positions, and five to seven times more in second codon positions than EF-1 $\alpha$ (Fig. 1). These two codon positions are far less saturated than third codon positions (Fig. 2), and hence of particular interest for older splits. Similarly, third codon positions of CAD have $17-29 \%$ more parsimony-informative characters than do those of EF-1 $\alpha$. Furthermore, third codon positions of EF-1 $\alpha$ have a very strong bias in base frequencies, which is not the case with CAD. Taking together these advantages of CAD and the availability of primers for CAD sequences twice as long as those for $\mathrm{EF}-1 \alpha$, the sequencing of CAD provides much better 'value for money' than the sequencing of EF- $1 \alpha$. This is the case not only within the Bombycoidea, but also for Tortricidae (Zwick, unpublished data) and most probably other Lepidoptera, too.

In this study of bombycoid phylogeny, the analyses of neither CAD nor EF- $1 \alpha$ sequence fragments result in a fully 
resolved, well-supported phylogenetic hypothesis. Within the densely sampled Anthelidae, younger splits are largely well resolved, whereas statistical support diminishes with increasing age of splits. Nevertheless, the BI analysis of only first and second codon positions (Fig. 6) and the partitioned Bremer support of the MP analysis (Fig. 3) show that the hypotheses within the Anthelidae are based almost entirely on third codon positions, even for the oldest splits within the Anthelinae. Even within the Anthelidae, however, third codon positions are significantly saturated for older splits (Fig. 2B, D), and hence these phylogenetic hypotheses of older splits have to be treated with caution. However, several of such splits with limited statistical support (here defined arbitrarily as less than $80 \%$ bootstrap or $95 \%$ posterior probability values) are strongly supported by concordance of the individual analyses of the two different genes (e.g. Miyamoto \& Fitch, 1995), which is stronger support than mere statistical support values. Such splits that are supported particularly strongly by their presence in both of the separate analyses of CAD and EF-1 $\alpha$ are marked in bold in the cladograms (Figs 3-6).

\section{Anthelid phylogeny}

The monophyly of Anthelidae is an example of an older node based on largely saturated third codon positions only, but which is strongly supported by concordance between $\mathrm{CAD}$ and $\mathrm{EF}-1 \alpha$ as well as by statistical support values. Similarly, the monophyly of the anthelid subfamilies Munychryiinae and Anthelinae is supported strongly by concordance and statistical support values.

Munychryiinae. Within the Munychryiinae, the monophyly of Munychryia is supported, with Gephyroneura remaining as a monotypic genus. As $G$. cosmia and $M$. senicula are superficially very similar, and because monotypic genera per se are in principle uninformative, it may seem justified to synonymize the two genera. However, several undescribed Munychryia species as well as an undescribed munychryiine genus exist in the ANIC, with the undescribed genus most probably being the sister group to Gephyroneura + Munychryia. Hence, I propose to retain Gephyroneura and Munychryia as separate genera in order to reflect the closer relationship between the various species of Munychryia compared with Gephyroneura and the undescribed genus.

Anthelinae. Within the Anthelinae, the position of Chelepteryx as the sister group to all other Anthelinae is moderately supported by statistical support values, but in addition strongly by the concordance between CAD and EF-1 $\alpha$. The placement of the endemic New Guinean genus Pseudodreata as sister group to the monophylum of all remaining Anthelinae is less well supported, because the monophyly of these remaining Anthelinae is not supported statistically in the combined analyses and is not recovered by any analysis of individual genes. Hence, the relationships between Pseudodreata, the monophylum including Anthela ferruginosa, and the moderately to well-supported monophylum of the remaining Anthelinae should be regarded as unresolved or at best tentative. Within the latter monophylum, the monotypic genus Chenuala and an undescribed species from northern Queensland form a statistically wellsupported monophylum. The terminal branches of these taxa are distinctly longer than those for any other antheline species, and the proposed relationship is supported only by third codon positions. However, the consistent recovery by both process-dependent methods of analysis in individual and combined analyses of both genes argues against an artificial grouping owing to long-branch attraction or by chance similarity of third codon positions caused by saturation. The proposed sister group of this enlarged genus Chenuala is a very well-supported monophylum that comprises the majority of all anthelid species. It includes six very well-supported smaller and in some cases well-resolved monophyla, but relationships between these monophyla essentially are unresolved. Because this large polytomy is located between highly supported older and younger splits, this lack of resolution and support cannot be explained simply by saturation or too constant sequences. Branch lengths between these monophyla are extremely short (Figs 4, 5), which could have resulted from an explosive radiation. Rapid radiations are difficult to track with any kind of marker because of very short shared evolutionary histories (Whitfield \& Lockhart, 2007), and it is this same polytomy of monophyla that is difficult to resolve with morphological characters, too (Zwick, in prep.).

By far the largest monophylum within this polytomy is the highly supported species group with $A$. euryphrica as the sister group to all other members. Relationships within the latter group are poorly supported in the combined analyses, and the topologies supported by the individual analyses of the two genes are conflicting. This monophylum not only is particularly species-rich but consists of several cryptic species complexes and has the widest distribution amongst the Anthelidae - it is ubiquitous in Australia and New Guinea and extends as far as to the Aru archipelago (Indonesia). Also included in the large polytomy is the genus Pterolocera, which is represented only by a single species in the analyses. However, a second species had been sequenced incompletely, and its sequence hardly differs

Fig. 3. Maximum parsimony analysis of the combined CAD (680 bp) and EF-1 $\alpha$ (1240 bp) sequences - strict consensus tree of the three most parsimonious trees ( 4480 steps; $\mathrm{CI}=0.29 ; \mathrm{RI}=0.48)$. Numbers below branches are bootstrap percentages $\geq 50 \%$ ( 1000 bootstrap replicates) of the combined sequences, followed below by bootstrap percentages of individual CAD and EF-1 $\alpha$ analyses, and further below by partitioned Bremer support values of 1 st/2nd/3rd codon positions for CAD and EF-1 $\alpha$. Splits particularly well supported by concordance between individual CAD and EF- $1 \alpha$ analyses are marked in bold; see Appendix 1 for abbreviations of family names. 


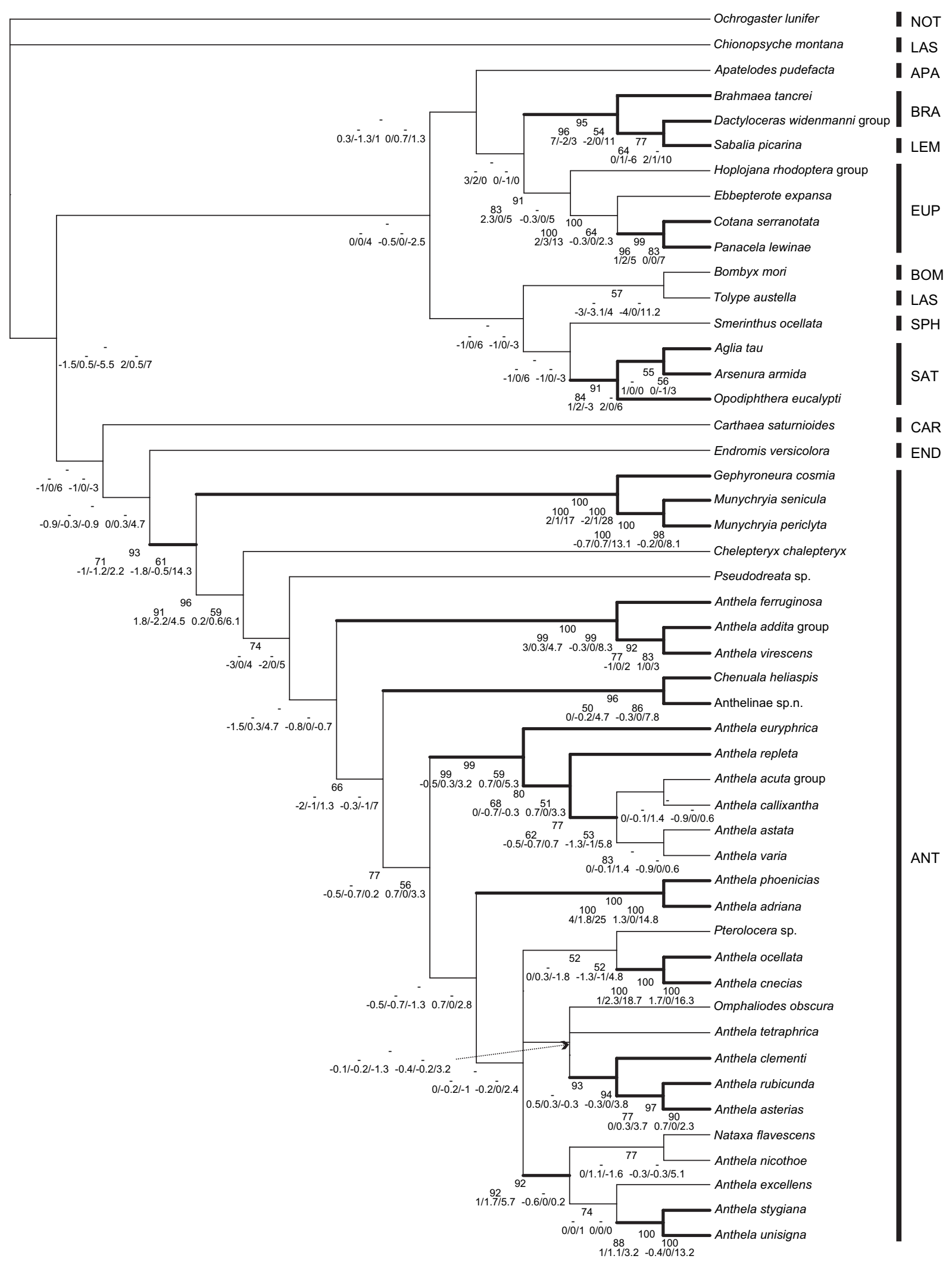


from the one of the included species. Furthermore, this group can be very well defined by male genitalia structures and its apterous females. The only exceptions to this are $P$. isogama and an undescribed sibling species, which both have fully winged females and very different male genitalia structures. No suitable specimens of these two species could be obtained for sequencing, and their tentative inclusion in Pterolocera is based on morphology alone (Zwick, in prep.). Within the large polytomy, two small and very distinct monophyla were consistently recovered, namely $A$. phoenicias $+A$. adriana and $A$. ocellata $+A$. cnecias. The former are representatives of cryptic species complexes of small, reddish or grey anthelid species from primarily dry and semi-arid areas of Australia and New Guinea. A further consistently recovered monophylum comprises $A$. clementi, $A$. rubicunda and $A$. asterias. Two other taxa, the monotypic genus Omphaliodes and $A$. tetraphrica, are frequently grouped with this monophylum, but inconsistently and with variable topology. The remaining Anthelinae included in the polytomy form a very wellsupported monophylum with a topology that is recovered consistently in all analyses. It includes a number of species with very contrasting habitus, namely the tiny, narrowwinged species of the genus Nataxa, against the large to very large and broad-winged $A$. nicothoe, $A$. excellens, A. stygiana and A. unisigna.

At present, the genus Anthela includes $80 \%$ of all described anthelid species. The phylogenetic analyses demonstrate clearly that the genus as currently perceived is not monophyletic, but paraphyletic relative to the majority of anthelid genera, namely Chenuala, Pterolocera, Omphaliodes, Nataxa and possibly Pseudodreata. The type species of the genus Anthela is A.ferruginosa, which is included in a small, very well-supported monophylum. Hence, it seems sensible strongly to restrict Anthela and to subdivide the remaining Anthela species into genera based on the well-supported monophyla described in the previous paragraph. For several of these monophyla, published names currently in synonymy with Anthela are already available, and a separate publication with the formal taxonomic acts required to subdivide Anthela, the (re-) definition of all anthelid genera and a revised checklist of all species is in preparation (Zwick, in prep.).

\section{Bombycoid phylogeny}

Anthelidae. The results of this study are inconclusive in respect of the placement of the Anthelidae as well as of the Lasiocampidae. Hence, their inclusion in a separate superfamily Lasiocampoidea as sister taxa (Minet, 1991) is neither recovered nor refuted. However, the monophylum comprising Lasiocampidae, Anthelidae, Lemoniidae,
Eupterotidae and Apatelodidae as proposed by Kuznetzov \& Stekolnikov (2001) is strongly refuted as it is paraphyletic relative to Brahmaeidae, which Kuznetzov \& Stekolnikov (2001) included in Bombycoidea sensu stricto.

Lasiocampidae. Although the placement of the Lasiocampidae within the Bombycoidea remains uncertain, a monophylum of the three lasiocampid species included in this study is strongly supported in analyses of CAD and CAD + EF- $1 \alpha$ (except for the combined MP analysis in Fig. 3), including in analyses without third codon positions (Supplementary Material Sm1). Analyses of EF-1 $\alpha$ alone, which lack one of the three species, do not recover Chionopsyche montana and Tolype austella as sister taxa, but instead place T. austella as the sister taxon of Bombyx mori (Bombycidae). This statistically unsupported placement is based only on strongly saturated third codon positions of EF-1 $\alpha$ and is probably incorrect. Obviously, three species are not representative of a family of 2200 species (species number according to Holloway et al., 1987), and the recovery of the family as monophyletic here seems rather meaningless. However, the significance lies in the inclusion of Chionopsyche montana (Chionopsychinae). The Chionopsychinae comprise only two species, $C$. montana and $C$. grisea, and have so far only been known from the two male holotypes in the Natural History Museum (NHM) in London. Very little is known about the subfamily other than its unique wing venation, the number of tibial spurs (0-2-4; all other Lasiocampidae have a reduced number of $0-2-2$ or fewer), and the absence of a chaetosema-like sense organ on the labial palps, which is present in all other Lasiocampidae (Minet, 1994; Zwick, 2001). Consequently, Minet (1994: 69) regarded Chionopsyche as possibly 'the most primitive lasiocampid genus', but the inclusion of the Chionopsychinae in the Lasiocampidae is morphologically only poorly supported. By contrast, the monophyly of the remaining Lasiocampidae is highly supported by the presence of the chaetosema-like sense organ, which is a unique and relatively complex structure. Hence, owing to the inclusion of $C$. montana and its placement as the sister group to the remaining Lasiocampidae (Macromphaliinae + Lasiocampinae; Poecilocampinae and Chondrosteginae are not represented), this molecular result does in fact provide very strong support for the monophyly of the family Lasiocampidae.

Carthaeidae. Carthaea saturnioides is the only species of the monotypic family Carthaeidae, which Common (1966: 36) considered to possibly be 'the most primitive family of the Bombycoidea' and which occurs only in the southwest of Western Australia. The results of this study are inconclusive regarding the phylogenetic position of $C$. saturnioides. Because it is not included in any other bombycoid family, its isolation in a monotypic family is not refuted.

Fig. 4. Maximum likelihood analysis (GTR $+\mathrm{I}+\Gamma+\mathrm{G})$ of the combined CAD (680 bp) and EF-1 $\alpha(1240$ bp) sequences - phylogram ( $\log$-likelihood score $=-24,730)$. Numbers below branches are bootstrap percentages $\geq 50 \%$ (1000 bootstrap replicates) of the combined sequences, followed below by bootstrap percentages of individual CAD and EF- $1 \alpha$ analyses. Splits particularly well supported by concordance between individual CAD and EF-1 $\alpha$ analyses are marked in bold; see Appendix 1 for abbreviations of family names. 


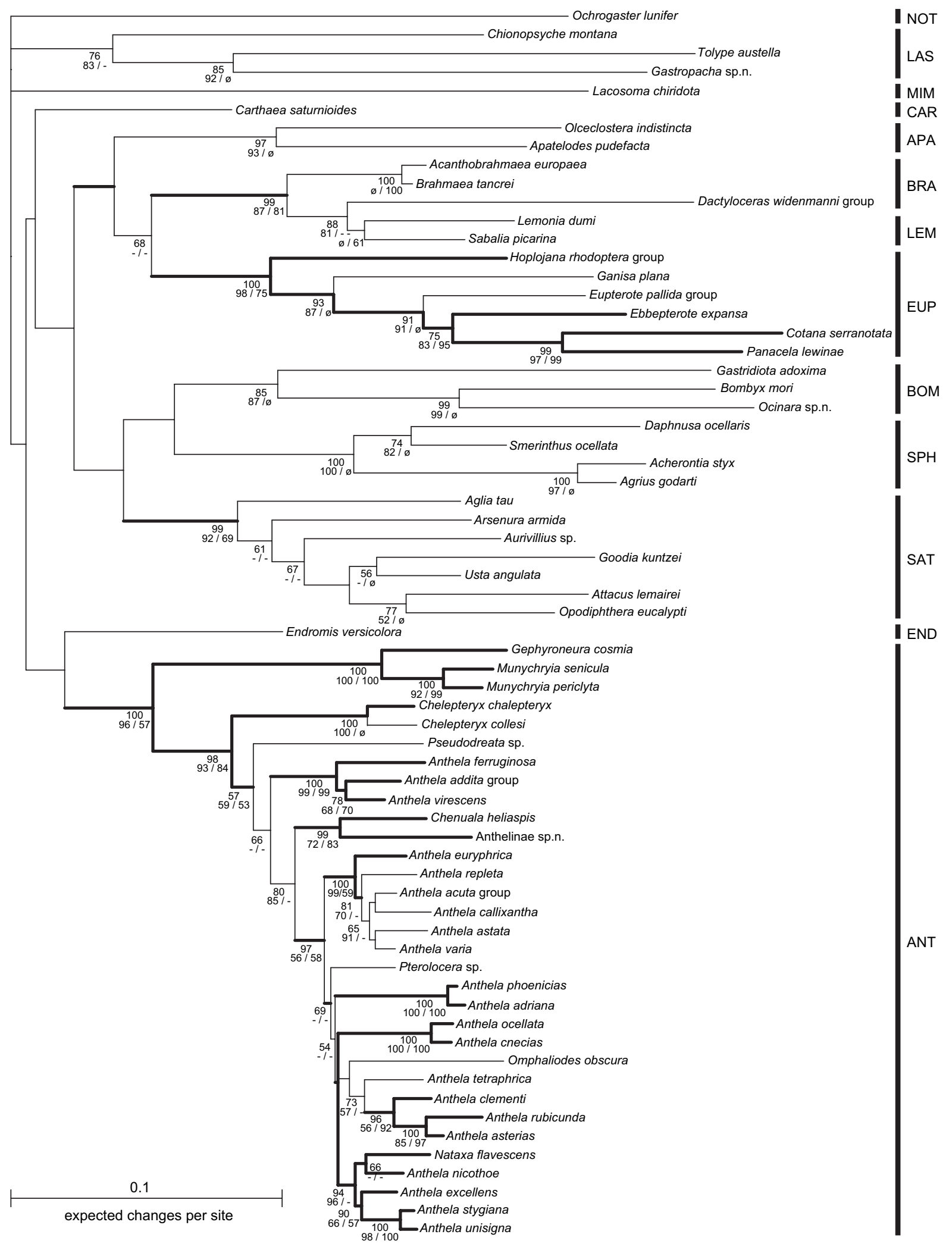


Brahmaeidae and Lemoniidae. The Brahmaeidae and Lemoniidae are restricted to Africa and the Palaearctic and include only approximately 20 species each in five and two genera, respectively. Based on morphological similarities, a very close relationship between Brahmaeidae and Lemoniidae has already been postulated by Hampson (1901), Jordan (1923), Forbes (1955), Minet (1994), Oberprieler \& Duke (1994), and Oberprieler et al. (2003). Such a close relationship was strongly supported by the molecular study of Regier et al. (2000), which proposes a sister-group relationship between the two families based on the three Palaearctic genera sampled, namely Brahmaea, Acanthobrahmaea (both Brahmaeidae) and Lemonia (Lemoniidae). The results of the present study support a monophylum consisting of Brahmaeidae and Lemoniidae very strongly in all analyses of both genes. However, it is the first molecular study to include the African genera Dactyloceras (Brahmaeidae) and Sabalia (Lemoniidae), which results in phylogenetic hypotheses significant for the classification of the two families. The monophylum of Brahmaea and Acanthobrahmaea is the sister group to the consistently recovered monophylum of Dactyloceras and the Lemoniidae. Within the latter monophylum, Dactyloceras is placed either as the sister taxon to the monophyletic Lemoniidae $($ Sabalia + Lemonia $)$ or the relationships are unresolved (BI of the combined data, Fig. 5), which might be a result of the lack of CAD data for Lemonia dumi. Irrespective of the relationships within the monophylum of Dactyloceras and Lemoniidae, this monophyly renders the family Brahmaeidae paraphyletic with respect to the family Lemoniidae. To resolve this conflict, the two families either would have to be synonymized, or Dactyloceras would have to be transferred from Brahmaeidae to Lemoniidae. Because Dactyloceras shares a unique wing pattern with Brahmaea and Acanthobrahmaea, and because the phylogenetic position of the brahmaeid genera Calliprogonos and Spiramiopsis [inclusion questionable; see Oberprieler \& Duke (1994)] is still unknown, I prefer the former option and regard Sabalia and Lemonia as derived Brahmaeidae. Hence, I retain the older family name Brahmaeidae Swinhoe, 1892 and synonymize the younger Lemoniidae Neumoegen \& Dyar, $1894^{3}$ syn.nov. with it. With this proposed phylogeny and new synonymy, the brahmaeid synapomorphies proposed by Lemaire \& Minet (1998) have to be reassessed. For example, a particularly short discoidal cell of the hindwing, is present also in some other bombycoid families, namely Chionopsychinae (Lasiocampidae), some Arsenurinae (Saturniidae) and some Sphingidae. Additionally, a number of transverse, parallel, wavy lines on the underside of the hindwing, are not present in all taxa included in Brahmaeidae by Lemaire \& Minet (1998), because it is absent in the poorly known Calliprogonos (Lemaire \& Minet, 1998).

\footnotetext{
${ }^{3}$ The authorship of the family-group name Lemoniidae is generally attributed to Hampson, 1918 (e.g. Fletcher \& Nye 1982), but should be attributed to Neumoegen \& Dyar, 1894b, as pointed out by Nässig and Oberprieler (2007).
}

Eupterotidae. The Eupterotidae are a phylogenetically and taxonomically poorly understood family, for which Minet (1994) proposed three defining synapomorphies. Two of these were rejected convincingly by Oberprieler et al. (2003) on the basis of occurrence in other bombycoid families and/or questionable quality of the characters. This leaves the family defined by a single synapomorphy, an elongate and dorsally pointed 'notal incision' (sensu Sharplin, 1963) on the mesothorax (Lemaire \& Minet, 1998). However, a 'notal incision' of this type occurs in some other bombycoid families, for example Brahmaeidae and Lemoniidae (Minet, 1994: 77), which are most probably the sister group of the Eupterotidae (see below). Although no characters to the contrary have been published, the monophyly of the Eupterotidae remains to be tested. The taxa sampled in this study represent all of the five eupterotid lineages identified by Oberprieler et al. (2003): the Ganisa group (Ganisa), the Janinae (Hoplojana), the Striphnopteryginae (Ebbepterote), the Panacelinae (Panacela) and the Eupterotinae (Eupterote, Cotana). They form a very well-supported monophylum in all analyses, despite the fact that two species lack EF-1 $\alpha$ sequences. At first glance, this appears to provide some urgently needed support for the monophyly of the family Eupterotidae. However, the proposed phylogeny contradicts the assignment by Oberprieler et al. (2003) of some of the taxa to certain lineages, which in turn casts doubt on whether all lineages actually were represented in this study.

The Australian fauna of Eupterotidae is very small, consisting of three genera with a total of only six species. However, the three genera were placed in different tribes and subfamilies by Forbes (1955), namely the Eupterotini, monotypic Cotanini (both Eupterotinae) and monotypic Panacelinae. Based on the sinuous Radius sector $1+2$ in the forewing venation, Minet (1994) included Cotanini in Panacelinae. Oberprieler et al. (2003) disputed this character of wing venation and used characters of male genital structures and larvae to argue against this placement of Cotanini and for its inclusion in Eupterotinae. They included tentatively the New Guinean genera Melanergon, Paracydas, Rarisquamosa and Lasiomorpha in Cotanini, and restricted Panacelinae to the genus Panacela. Furthermore, they recognized the unique nature of the Australian 'Eupterote' expansa (Eupterotinae: Eupterotini) and erected for it the monotypic genus Ebbepterote in the African subfamily Striphnopteryginae, on the basis of several characteristics of male genital structures.

The phylogeny proposed in this study is statistically very well supported and recovered consistently in all analyses of both genes (within the limitations of the two missing EF-1 $\alpha$ sequences; Figs 3-5), including the analyses without third codon positions (Fig. 6). It very strongly supports a sistergroup relationship between Panacela and Cotana, as well as between Panacela + Cotana and Ebbepterote and between Panacela + Cotana + Ebbepterote and Eupterote. These relationships are in stark contrast to the current placement of Cotanini in Eupterotinae and of Ebbepterote in Striphnopteryginae by Oberprieler et al. (2003). In the absence of additional taxa, several interpretations of the proposed 
phylogeny and consequential classification are possible. Unless Cotanini are elevated to subfamily rank or included in Panacelinae as proposed by Minet (1994), Eupterotinae are paraphyletic with respect to Striphnopteryginae and Panacelinae. Alternatively, Striphnopteryginae and Panacelinae would have to be downgraded to tribal level and be included in Eupterotinae. Furthermore, from a biogeographical point of view, the phylogeny indicates a spreading of Eupterotidae from Africa (Hoplojana, and potentially Striphnopteryginae sensu stricto) through Asia (Ganisa and Eupterote) to Australia (Ebbepterote, Cotana and Panacela). This is a more plausible scenario than that implied by the inclusion of the Australian Ebbepterote in the African Striphnopteryginae by Oberprieler et al. (2003). This inclusion argues for the existence of the Striphnopteryginae at a time that Africa and Australia were connected, because the dispersal capabilities of the Eupterotidae are, as in many other bombycoid taxa, severely limited by the very shortlived adults and by the rather sendentary nature of the females. However, such an old age of the Striphnopteryginae is counter-indicated by the phylogeny proposed here, which places the Australian taxa as the crown-group of the Eupterotidae. Moreover, the strong phylogenetic signal of the EF- $1 \alpha$ data for the Eupterotidae argues for a relatively young age of the group, because the phylogenetic utility of the third codon positions of EF- $1 \alpha$ in Noctuidae covers most of the Tertiary, but not beyond (Mitchell et al., 1997). Hence, the existence of Striphnopteryginae prior to the interruption of land bridges between Africa and Australia seems very unlikely. Therefore, the inclusion of the Ebbepterote in the Striphnopteryginae probably is incorrect, and it seems that no true Striphnopteryginae are included in this study. Consequently, this study does not present strong support for the monophyly of the Eupterotidae. The question of whether the Eupterotidae Swinhoe, 1892 including Striphnopteryginae Wallengren, 1858 form a monophylum or not seems to be of particular interest, as Striphnopteryginae is an older family-group name than the widely used family name Eupterotidae. However, the younger family-group name Eupterotidae is retained currently under the assumption of monophyly of the family and on the basis of article 35.5 of the code (ICZN 1999) by Nässig \& Oberprieler (2007).

This first molecular phylogeny of Eupterotidae is too limited to decide on the validity and status of eupterotid subfamilies. However, to resolve the most obvious contradiction of the subfamily classification, the paraphyly of Eupterotinae, I transfer Cotanini from Eupterotinae back to Panacelinae, as done initially by Minet (1994). This inclusion of the tribe Cotanini in the monotypic Panacelinae necessitates a monotypic tribe Panacelini, which is uninformative. However, given the uncertainty of the inclusion of Ebbepterote in Striphnopteryginae and our lack of knowledge of other New Guinean genera placed currently in Cotanini, I prefer not to abolish the tribe Cotanini prematurely. The proposed phylogeny demonstrates that a more comprehensive phylogenetic study of the Eupterotidae is urgently needed and that both CAD and EF-1 $\alpha$ are promising markers for such a task.
Brahmaeidae, Lemoniidae, Eupterotidae and Bombycidae. According to the phylogeny proposed by Minet (1994), the Brahmaeidae/Lemoniidae and Eupterotidae are not closely related but are separated in his two main lineages ['Ep-Sa' $($ Eupterotidae + Bombycidae + Endromidae + Mirinidae + Saturniidae), and Carthaeidae + 'L-S' (Lemoniidae + Brahmaeidae + Sphingidae)] within the Bombycoidea sensu stricto. The basis for this placement is rather questionable (see Zwick, 2006: Appendix P), and criticism of several of Minet's phylogenetic hypotheses has been voiced (e.g. Oberprieler \& Duke, 1994; Oberprieler et al., 2003). The analysis results of both CAD and EF-1 $\alpha$ (BI), and in particular of the combined gene analyses (all methods, Figs 3-5), further contradict the phylogenetic hypothesis of Minet by strongly supporting a sister-group relationship between Brahmaeidae/Lemoniidae and Eupterotidae, mainly by concordance between the individual analyses of $\mathrm{CAD}$ and $\mathrm{EF}-1 \alpha$.

A close relationship between Brahmaeidae/Lemoniidae, Eupterotidae and Bombycidae has been hypothesized for a long time (e.g. Mell, 1930; Forbes, 1955), but mainly as a result of difficulties in distinguishing between these families rather than on a phylogenetic basis. In this context it is noteworthy that the concept of the Eupterotidae at times included the subfamilies Apatelodinae and Prismostictinae, both of which have, in the past as now, been placed in the family Bombycidae. A potential synapomorphy for Brahmaeidae/Lemoniidae, Eupterotidae and Apatelodinae results from the discussion by Oberprieler et al. (2003) of a midventral row of spines on the female metatarsus; such spines are also present in Xenosphingia jansei Jordan, 1920, but the inclusion of this 'odd' taxon in Sphingidae should be re-examined (Oberprieler \& Duke, 1994; Zwick, 2006). Such a monophylum is compatible with the phylogeny supported by EF- $1 \alpha$ and combined analyses, which places the Apatelodinae as sister group of Brahmaeidae/Lemoniidae + Eupterotidae. At the same time, the other Bombycidae included in this study (Bombyx mori, Ocinara sp.n. and Gastridiota adoxima) form a very well-supported monophylum placed rather distantly to Apatelodinae. This monophylum represents the subfamily Bombycinae, and the separation of Apatelodinae and Bombycinae as evidenced by molecular characters strongly argues for the current concept of Bombycidae (Lemaire \& Minet, 1998; based on Minet, 1994) to be polyphyletic. The inclusion of Apatelodinae in Bombycidae was regarded as only tentative by Lemaire \& Minet (1998, p. 331). Hence, Apatelodinae here are removed from Bombycidae and re-instated as a distinct family, Apatelodidae Neumoegen \& Dyar, $1894^{4}$ stat.rev..

\footnotetext{
${ }^{4}$ Fletcher \& Nye (1982: viii) attribute the authorship of the family-group name Apatelodinae to Neumoegen \& Dyar 1894b, which was published in September 1894. However, Neymoegen and Dyar had already used the name Apatelodinae in a publication in June 1894, and hence the correct publication for the authorship of the family-group name Apatelodinae is Neumoegen \& Dyar 1894a.
} 
Saturniidae. The seven saturniid species included in this study are recovered consistently as a monophylum by all analyses of both genes. By contrast, relationships within this monophylum are only poorly supported statistically and differ somewhat between the two genes in unsupported splits. Analyses of EF-1 $\alpha$ place Aglia tau (Agliinae) and Arsenura armida (Arsenurinae) as sister taxa, whereas analyses of CAD and CAD $+\mathrm{EF}-1 \alpha$ place $A$. tau as the sister taxon to $A$. armida plus all other sampled Saturniidae (all Saturniinae). The monophyly of the sampled Saturniinae is statistically variably supported, and the moderately to well-supported topology of the combined BI analysis (Fig. 5) is congruent with the results of Regier et al. (2002): Attacini (Attacus lemairei) and Saturniini (Opodiphthera eucalypti) form a well-supported monophylum, which is the sister group to a monophylum comprising the African tribes Bunaeini (Aurivillius sp.), Micragonini (Goodia kuntzei) and Urotini or Bunaeini (Usta angulata) sensu Oberprieler (1997). Like the results of Regier et al. (2002), this topology supports the inclusion of Micragonini sensu Oberprieler (1997) within the Saturniinae and contradicts their separation as a subfamily Ludiinae sensu Lemaire \& Minet (1998), irrespective of the junior homonymy of the name Ludiinae as pointed out by Oberprieler (1997).

Bombycoidea. The falsification of sensu Minet's (1994) two main lineages of the Bombycoidea s. auct., 'Ep-Sa' and Carthaeidae + 'L-S', casts doubt on many of his other phylogenetic hypotheses. Many of the characters proposed as synapomorphies of monophyla occur outside these monophyla and are regarded only as synapomorphies because of their placement in more inclusive monophyla that lack these synapomorphies. By falsifying the monophyly of the main lineages, this system collapses, and the current interpretation of many of the proposed characters as apomorphic or plesiomorphic becomes highly questionable. This is particularly true for the many homoplastic characters of Minet (1994).

The results of this study resolve relationships only between a few bombycoid families and by no means of the entire Bombycoidea, but at the same time they discredit widely accepted phylogenetic hypotheses. They demonstrate how limited our understanding of relationships within the Bombycoidea is, and that a thorough study of the phylogeny of the group is urgently needed. At present, we lack a predictive framework for the interpretation of the many data accumulated for some bombycoid families, and particularly for the many important bombycoid model organisms.

Patterns of host plant usage by Anthelidae. The current taxonomy of Anthelidae (and of the vast majority of
Lepidoptera in general) is based exclusively on adults, as they are the most readily collected life stage, and the one that is particularly rich in morphological characters. However, the general public takes notice of Anthelidae only when encountering their pre-imaginal instars - numerous medical incidents involving larval hairs have been recorded, in particular for Chelepteryx collesi (e.g. Mulvaney et al., 1998) and Anthela nicothoe (e.g. Lee, 1961, 1975; Bishop \& Morton, 1967, 1968). Moreover, several anthelid species have been recorded as (generally minor and temporary) pests of crops, in particular in pine plantations (e.g. Hadlington, 1963; Moore, 1963, 1964; Common, 1970, 1990; Campbell, 1972; Hardy et al., 1979) and of pastures (e.g. French, 1911; Leach, 1952; Hadlington, 1963; Moore, 1963, 1964; Common, 1970, 1990; Campbell, 1972; Hardy et al., 1979, and Edwards \& Fairey, 1996). The latter pest record is remarkable, because no fewer than five anthelid species (Pterolocera spp., Anthela ocellata, A. basigera, A. euryphrica and $A$. ostra), in what have been regarded as three unrelated species groups, have been recorded as pests of pastures, whereas feeding on grasses is generally uncommon amongst Macrolepidoptera.

The question of how often grassfeeding might have evolved within the Anthelidae is addressed in Fig. 6, in which host records are mapped onto the best phylogenetic hypothesis (BI analysis of CAD $+\mathrm{EF}-1 \alpha$ ), using parsimony to reconstruct ancestral host records. However, published host records have to be interpreted with great caution. Typically, the implied definition of what constitutes a host record varies strongly between authors, and the mere observation of a larva feeding on a certain plant might give a false impression that it can sustain a population in the long run. In the case of the Anthelidae, many records refer to mature larvae that came across different plants during a wandering phase prior to pupation or that indiscriminately 'attacked' available plants because of a shortage of their host plant [e.g. Terauds et al. (1986) reported a Pterolocera sp. as feeding on various garden plants, but this only occurred after native pastures had been devoured]. Furthermore, reliable identification of anthelid species based on the literature (rather than on a reference collection) is very difficult at best, and the lack of published descriptions of correctly identified larvae constitutes an even bigger hurdle when it comes to establishing host records. Hence, the host records mapped in Fig. 6 are largely based on my own observations and larval rearing records in the ANIC.

The range of published host records of Anthelidae is huge [for a comprehensive list, see Zwick (2006): Appendix C], but if restricted to reliable records only, four distinct groups of hosts clearly dominate: Casuarina/Allocasuarina

Fig. 5. Bayesian inference analysis (GTR $+\mathrm{I}+\Gamma+\mathrm{G})$ of the combined CAD (680 bp) and EF-1 $\alpha$ (1240 bp) sequences, partitioned by codon position and, for third codon positions only, gene (1st/2nd/3rd CAD/3rd EF-1 $\alpha$ ) - phylogram (six pooled runs; arithmetic mean log-likelihood score $=-23$ 739). Numbers below branches are posterior probabilities $\geq 50 \%$ of the combined sequences, followed below by posterior probabilities of individual CAD and EF- $1 \alpha$ analyses. Splits particularly well supported by concordance between individual CAD and EF-1 $\alpha$ analyses are marked in bold; see Appendix 1 for abbreviations of family names. 


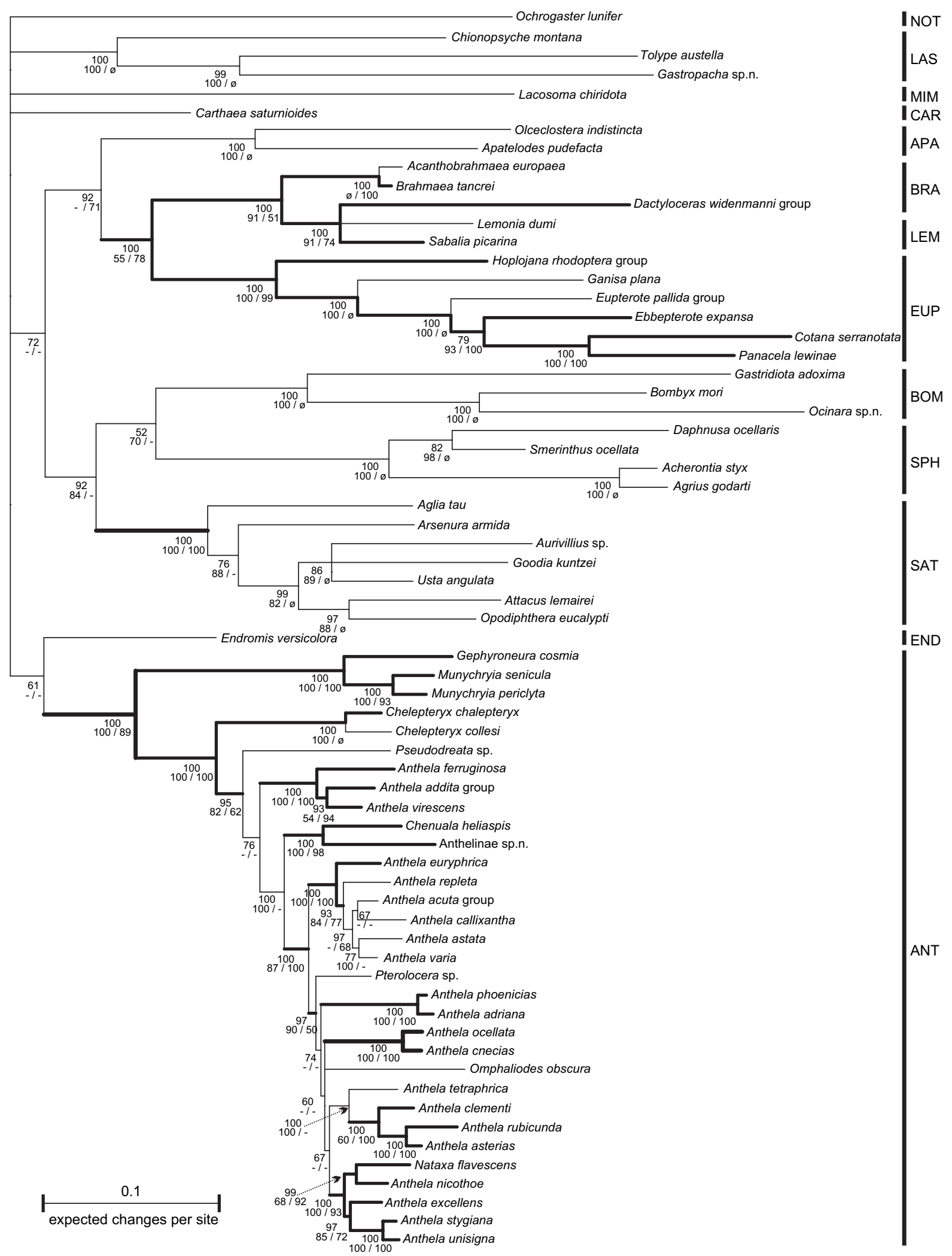

(C) 2008 The Author

Journal compilation (C) 2008 The Royal Entomological Society, Systematic Entomology, 33, 190-209 


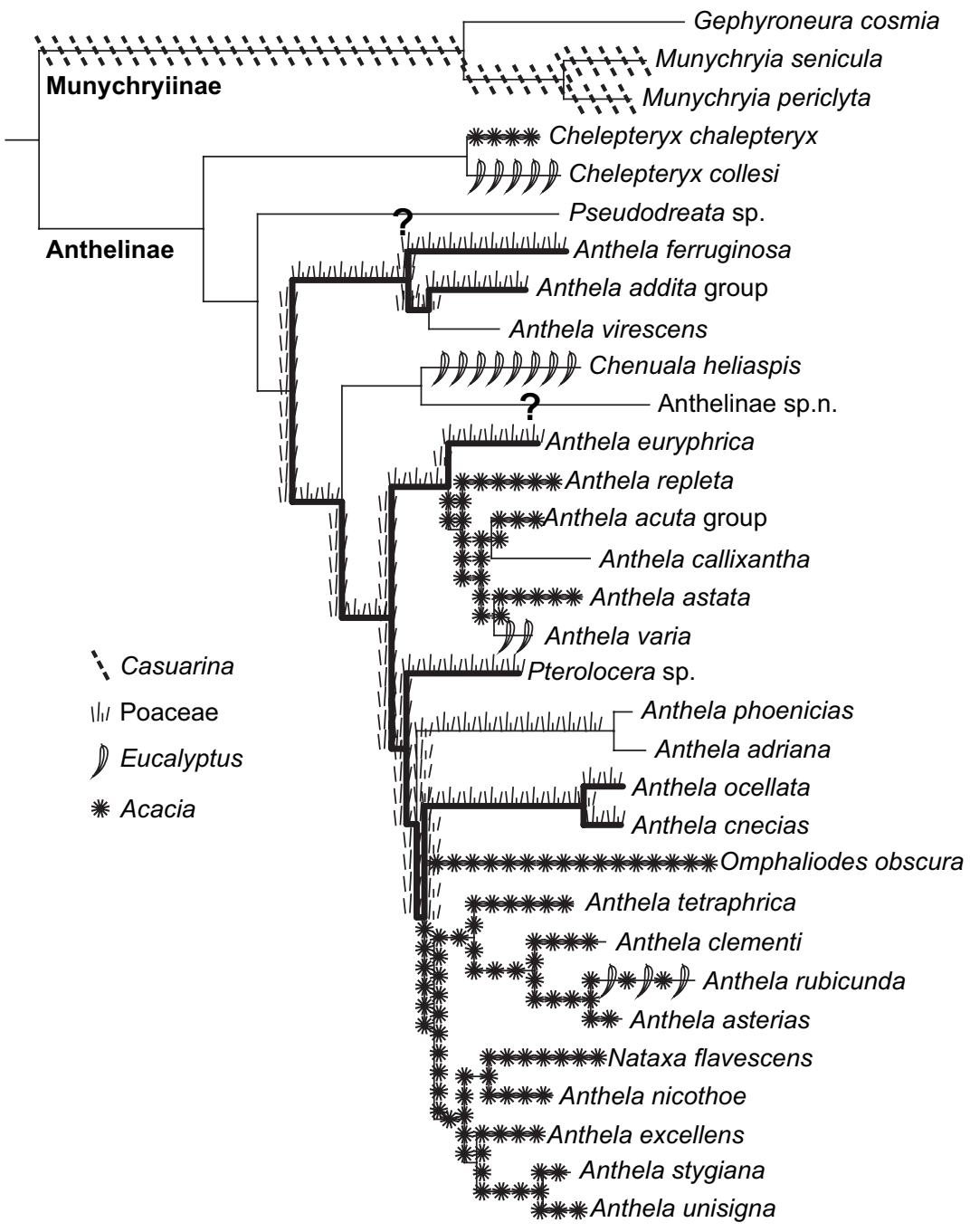

Fig. 6. Anthelid host records mapped onto the phylogram derived by Bayesian inference analysis of the combined CAD (680 bp) and EF-1 $\alpha$ (1240 bp) sequences (Fig. 5); ancestral states are reconstructed using parsimony.
(Casuarinaceae), grasses (Poaceae), Acacia (Mimosaceae) and Eucalyptus (Myrtaceae).

The anthelid subfamily Munychryiinae is known to feed only on Casuarinaceae and has a highly derived larva with some extreme adaptations to enable it to blend in with the equisetoid twigs it feeds on. The host record and description of the larva have been published for the genus Munychryia (Common \& McFarland, 1970), but the pre-imaginal instars and the female of Gephyroneura remain unknown. However, the larva of the undescribed munychryiine genus and species from western Australia is very similar to that of Munychryia and also feeds on Casuarinaceae. Because this genus is most probably the sister taxon to Munychryia + Gephyroneura (Zwick, in prep.), this larval habitus and host association are postulated to be characteristic of the entire subfamily Munychryiinae.

Within the Anthelinae, the two species of Chelepteryx each feed on a different group of hosts, namely Acacia and Eucalyptus species. Gallard (1931) recorded C. chalepteryx as occasionally also feeding on grass, but clearly this is not a regular host for this species. Within the large monophylum that includes $A$. euryphrica, the range of host records is by far the broadest, as is the number of cryptic species and of host records attributed incorrectly to A. acuta. However, most species (including the sampled species) feed consistently on Acacia species, or in the case of $A$. varia on Eucalyptus. Anthela callixantha is unusual in that it feeds on native Solanum species (Solanaceae; ANIC record). The larvae of $A$. phoenicias and $A$. adriana remain unknown, but a sibling species in the cryptic species complex they represent feeds on grasses. The small monophylum of $A$. ocellata and $A$. cnecias has been recorded consistently as feeding on grasses. Although no specimens were available for sequencing, apomorphies in male genital structures argue strongly for an inclusion of the odd-looking, grass-feeding A. ostra in this monophylum. The larva of Omphaliodes obscura is known only from a single specimen found and reared on Acacia leiophylla (Jenkins, 2002). 
It is apparent from Fig. 6 that grass feeding is even more widespread within the Anthelinae than is known from pest records, as is the feeding on Acacia. Because of the distribution of grass feeding in the proposed phylogeny and because it is rare among Macrolepidoptera but widespread within Anthelinae, it seems plausible that feeding on grasses is an ancestral trait within at least a large part of the Anthelinae, rather than that it evolved several times independently. The record of occasional acceptance of grasses by Chelepteryx chalepteryx (Gallard, 1931) might indicate that it is even an ancestral trait of all Anthelinae.

\section{Supplementary material}

Supplementary data is available in the full text version of this article from http://www.blackwell-synergy.com. under DOI reference doi:10.1111/j.1365-3113.2007.00410.x

SM1 - combined CAD and EF- $1 \alpha$ analysis, excluding 3rd codon.

ST1 - Primer sequences and sources.

ST2 - Thermocycler touch-down program used to amplify all fragments.

\section{Acknowledgements}

This study was in part supported by an Endeavour International Postgraduate Research Scholarships (IPRS) from the Australian Department of Education, Science and Training (DEST), a Ph.D. scholarship from the Faculty of Sciences at the Australian National University (ANU) in Canberra and in kind by the Australian National Insect Collection (ANIC) at CSIRO Entomology in Canberra, all of which are gratefully acknowledged. I thank John Trueman (ANU), David Yeates and Rolf Oberprieler (both ANIC) for supervising the Ph.D. project that this study is partly based on, as well as David Morris (ANU), Marianne Horak, Ted Edwards, Glenn Cocking, Rolf Oberprieler, Stephen Cameron (all ANIC) and Chris Lambkin (Queensland Museum, Australia) for their support, discussions and constructive comments on the manuscript. Further, I am indebted to Umani Springs Ecotourism Camp (Kenya) for permitting me collect moths on their property, to Bruce Walsh (University of Arizona, U.S.A.), my late friend Bozik Rinn (Studnice, Czechia), Gerhard Weber (Adelaide, Australia) and Glenn Cocking for contributing samples, and to Lorraine Jenkins (Port Lincoln Junior Primary School, Australia) for making photos of the hitherto unknown larva of Omphaliodes obscura available.

\section{References}

Baker, R.H., Yu, X. \& DeSalle, R. (1998) Assessing the relative contribution of molecular and morphological characters in simultaneous analysis trees. Molecular Phylogenetics and Evolution, 9, $427-436$.
Bishop, J.W. \& Morton, M.R. (1967) Caterpillar-hair keratoconjunctivitis. American Journal of Ophthalmology, 64, 778-779.

Bishop, J.W. \& Morton, M.R. (1968) Caterpillar-hair keratoconjunctivitis. Medical Journal of Australia, 2, 995-997.

Brock, J.P. (1971) A contribution towards an understanding of the morphology and phylogeny of the ditrysian Lepidoptera. Journal of Natural History, 5, 29-102.

Campbell, K.G. (1972) Insect hazard in monoculture tree plantations (as opposed to mixed planting and natural forest associations in Australia). Forestry Log, 5, 42-44.

Common, I.F.B. (1966) A new family of Bombycoidea (Lepidoptera) based on Carthaea saturnioides Walker from Western Australia. Journal of the Australian Entomological Society, 5, 29-36.

Common, I.F.B. (1970) Lepidoptera (moths and butterflies). The Insects of Australia (ed. by I. M. Mackerras), pp. 765-866, pls 7-8. Melbourne University Press, Carlton.

Common, I.F.B. (1990) Moths of Australia. Melbourne University Press, Carlton.

Common, I.F.B. \& McFarland, A.N. (1970) A new subfamily for Munychryia Walker and Gephyroneura Turner (Lepidoptera: Anthelidae) and the description of a new species from Western Australia. Journal of the Australian Entomological Society, 9, $11-22$.

Edwards, E.D. \& Fairey, K.D. (1996) Anthelidae. Checklist of the Lepidoptera of Australia (ed. by E. S. Nielsen, E. D. Edwards and T. V. Rangsi), pp. 258-260. CSIRO Publishing, Collingwood.

Ewing, B. \& Green, P. (1998) Base-calling of automated sequencer traces using Phred. II. Error probabilities. Genome Research, 8, 186-194.

Ewing, B., Hillier, L., Wendl, M.C. \& Green, P. (1998) Base-calling of automated sequencer traces using phred. I. Accuracy assessment. Genome Research, 8, 175-185.

Fänger, H. (1999) Comparative morphology of tergal phragmata occurring in the dorsal thoraco-abdominal junction of ditrysian Lepidoptera (Insecta). Zoomorphology, 119, 163-183.

Fletcher, D.S. \& Nye, I.W.B. (1982) Bombycoidea, Castnioidea, Cossoidea, Mimallonoidea, Sesioidea, Sphingoidea, Zygaenoidea. British Museum (Natural History), London.

Forbes, W.T.M. (1955) The subdivision of the Eupterotidae (Lepidoptera). Tijdschrift voor Entomologie, 98, 85-132.

French, C.S. (1911) A Handbook of the Destructive Insects of Victoria, with Notes on the Methods of Prevention and Extirpation [Part V]. Government Printer, Melbourne.

Gallard, L. (1931) Notes on the development of Chelepteryx felderi, Turner (Anthelidae). Australian Naturalist, 8, 116-117.

Galtier, N., Gouy, M. \& Gautier, C. (1996) SEAVIEW and PHYLO_WIN: two graphic tools for sequence alignment and molecular phylogeny. Computer Applications in the Biosciences, 12, 543-548.

Gordon, D., Abajian, C. \& Green, P. (1998) Consed: a graphical tool for sequence finishing. Genome Research, 8, 195-202.

Hadlington, P.W. (1963) A Pest of Pine. Forestry Commission of N.S.W., Sydney.

Hardy, R.J., Terauds, A., Rapley, P.E.L. et al. (1979) Insect pest occurrences in Tasmania, 1977/78. Insect Pest Survey, pp. [3]+34. Tasmanian Department of Agriculture, Hobart.

Holloway, J.D., Bradley, J.D. \& Carter, J.D. (1987). Lepidoptera. CIE Guides to Insects of Importance to Man (ed. by C. R. Betts), Vol. 1. CAB International, Wallingford.

Hampson, G.F. (1901) A classification of a new family of the Lepidoptera. Transactions of the Entomological Society of London, 1901, 187-192. 
Huelsenbeck, J.P. \& Ronquist, F. (2001) MRBAYES: Bayesian inference of phylogeny. Bioinformatics, 17, 754-755.

ICZN (1999) International code of Zoological Nomenclature, fourth edition, Adopted by the International Union of Biological Sciences. International Trust for Zoological Nomenclature (BMNH), London.

Jenkins, L. (2002) Moths of the Westcoast. Anthelidae [WWW document]. URL: http://www.lincolnjp.sa.edu.au/moths3/ anthelidae.htm [accessed January 2007].

Jordan, K. (1923) A note on the families of moths in which R2 $(=$ vein 5$)$ of the fore wing arises from near the centre or from above the centre of the cell. Novitates Zoologicae, 30, 163-166.

Kamiie, K., Taira, H., Ooura, H., Kakuta, A., Matsumoto, S., Ejiri, S. \& Katsumata, T. (1993) Nucleotide sequence of the cDNA encoding silk gland elongation factor 1 alpha. Nucleic Acids Research, 21, 742.

Kuznetzov, V.I. \& Stekolnikov, A.A. (1985) [Comparative and functional morphology of the male genitalia of the bombycoid moths (Lepidoptera, Papilionomorpha: Lasiocampoidea, Sphingoidea, Bombycoidea) and their systematic position] Proceedings of the Zoological Institute of the USSR Academy of Sciences, 134, 3-48 (in Russian, with English summary).

Kuznetzov, V.I. \& Stekolnikov, A.A. (2001) [New approaches to the system of Lepidoptera of world fauna (on the base of the functional morphology of abdomen)] Russian Academy of Sciences Proceedings of the Zoological Institute, 282, 5-462 (in Russian, with English summary).

Leach, J.A. (1952) Australian Nature Studies. A Book of Reference for Those Interested in Nature-Study. MacMillan \& Co. Limited, Melbourne.

Lee, D.J. (1961) Cause and Effect Relating to Arthropod Bites and Stings. School of Public Health and Tropical Medicine, University of Sydney, Sydney.

Lee, D.J. (1975) Arthropod Bites and Stings and Other Injurious Effects. School of Public Health and Tropical Medicine, University of Sydney, Sydney.

Lemaire, C. \& Minet, J. [1998 (1999)] 18. The Bombycoidea and their relatives. Handbook of Zoology 4(35). Lepidoptera, Moths and Butterflies Vol. 1 Evolution, systematics, and Biogeography (ed. by N. P. Kristensen), pp. 321-353. Walter de Gruyter, Berlin $\&$ New York.

Maddison, W.P. \& Maddison, D.R. (2007). Mesquite: A Modular System for Evolutionary Analysis. Version 2.0 [WWW document]. URL http://mesquiteproject.org [accessed September 2007].

Mell, R. [1930 (1929)] Beiträge zur Fauna sinica. V. Die Brahmaeiden und Eupterotiden Chinas. Deutsche Entomologische Zeitschrift, 1929, 337-494, pls III-XII.

Minet, J. (1986) Ébauche d'une classification moderne de l'ordre des Lépidoptères. Alexanor, 14, 291-313.

Minet, J. (1991) Tentative reconstruction of the ditrysian phylogeny (Lepidoptera: Glossata). Entomologica Scandinavica, 22, 69-95.

Minet, J. (1994) The Bombycoidea: phylogeny and higher classification (Lepidoptera: Glossata). Entomologica Scandinavica, 25, 63-88.

Mitchell, A., Cho, S., Regier, J.C., Mitter, C., Poole, R.W. \& Matthews, M. (1997) Phylogenetic utility of Elongation Factor-1 $\alpha$ in Noctuoidea (Insecta: Lepidoptera): the limits of synonymous substitution. Molecular Biology and Evolution, 14, 381-390.

Miyamoto, M.M. \& Fitch, W.M. (1995) Testing species phylogenies and phylogenetic methods with congruence. Systematic Biology, 44, 64-78.

Moore, K.M. (1963) Observations on some Australian forest insects. 14. A preliminary list of insects attacking Pinus species in New South Wales. Australian Zoologist, 13, 69-77.
Moore, K.M. [1964 (1963)] Observations on some Australian forest insects. 16. Lepidoptera attacking Pinus spp. in New South Wales. Proceedings of the Linnean Society of New South Wales, 88, 340-360, pl. 18.

Moulton, J.K. \& Wiegmann, B.M. (2004) Evolution and phylogenetic utility of CAD (rudimentary) among Mesozoic-aged Eremoneuran Diptera (Insecta). Molecular Phylogenetics and Evolution, 31, 363-378.

Mulvaney, J.K., Gatenby, P.A. \& Brookes, J.G. (1998) Lepidopterism: two cases of systemic reactions to the cocoon of a common moth, Chelepteryx collesi. Medical Journal of Australia, 168, 610-611.

Nässig, W.A. \& Oberprieler, R.G. (2007) The nomenclature of the family-group names of Eupterotidae (Bambycoidea). Nota lepidopterologica, 30, 315-327.

Neumoegen, B. \& Dyar, H.G. (1894a) A preliminary revision of the lepidopterous family Notodontidae. Transactions of the American Entomological Society, 21, 179-208.

Neumoegen, B. \& Dyar, H.G. (1894b) A preliminary revision of the Bombyces of America, North of Mexico [part]. Journal of the New York Entomological Society, 2, 109-132.

Niculescu, E.V. (1988) Recherches morphologiques et phylogénétiques sur les Bombycoidea (Lepidoptera: Parasternia). Shilap: revista de lepidopterologia, 16, 331-334.

Oberprieler, R.G. (1997) Classification of the African Saturniidae (Lepidoptera) - the quest for natural groups and relationships. Metamorphosis, (Occasional supplement 3), 142-155.

Oberprieler, R.G. \& Duke, N.J. (1994) The life history and immature stages of Spiramiopsis comma Hampson, 1901 (Lepidoptera: Bombycoidea), with comments on its taxonomic position and on preimaginal characters of the Bombycoidea. Nachrichten des Entomologischen Vereins Apollo, 15, 199-244.

Oberprieler, R.G., Nässig, W.A. \& Edwards, E.D. (2003) Ebbepterote, a new genus for the Australian 'Eupterote' expansa (T.P. Lucas), with a revised classification of the family Eupterotidae (Lepidoptera). Invertebrate Systematics, 17, 99-110.

Posada, D. \& Crandall, K.A. (1998) Modeltest: testing the model of DNA substitution. Bioinformatics, 14, 817-818.

Rambaut, A. \& Drummond, A.J. (2003) Tracer V1.3 [Computer Program] [WWW document]. URL http://evolve.zoo.ox.ac.uk/ software.html [accessed January 2007].

Regier, J.C. 2007. Protocols, Concepts, and Reagents for Preparing DNA Sequencing Templates. Version 4/30/07 [WWW document]. URL http://www.umbi.umd.edu/users/jcrlab/PCR_primers.pdf [accessed May 2007].

Regier, J.C. \& Shi, D. (2005) Increased yield of PCR product from degenerate primers with nondegenerate, nonhomologous $5^{\prime}$ tails. BioTechniques, 38, 34-38.

Regier, J.C., Fang, Q.Q., Mitter, C., Peigler, R.S., Friedlander, T.P. \& Solis, M.A. (1998) Evolution and phylogenetic utility of the period gene in Lepidoptera. Molecular Biology and Evolution, 15, 1172-1182.

Regier, J.C., Mitter, C., Peigler, R.S. \& Friedlander, T.P. (2000) Phylogenetic relationships in Lasiocampidae (Lepidoptera): initial evidence from elongation factor- $1 \alpha$ sequences. Insect Systematics and Evolution, 31, 179-186.

Regier, J.C., Mitter, C., Friedlander, T.P. \& Peigler, R.S. (2001) Re: phylogenetic relationships in Sphingidae (Insecta: Lepidoptera): initial evidence from two nuclear genes. Molecular Phylogenetics and Evolution, 20, 311-325.

Regier, J.C., Mitter, C., Peigler, R.S. \& Friedlander, T.P. (2002) Monophyly, composition, and relationships within Saturniinae (Lepidoptera: Saturniidae): evidence from two nuclear genes. Insect Systematics and Evolution, 33, 9-21. 
Regier, J.C., Cook, C.P., Mitter, C. \& Hussey, A. (2008) A phylogenetic study of the 'bombycoid complex' (Lepidoptera) using five proteincoding nuclear genes, with comments on the problem of macrolepidopteran phylogeny. Systematic Entomology, 33, 175-189.

Ronquist, F. \& Huelsenbeck, J.P. (2003) MrBayes 3: Bayesian phylogenetic inference under mixed models. Bioinformatics, 19, 1572-1574.

Scott, J.A. (1986) On the monophyly of the Macrolepidoptera, including a reassessment of their relationship to Cossoidea and Castnioidea, and a reassignment of Mimallonidae to Pyraloidea. The Journal of Research on the Lepidoptera, 25, 30-38.

Sharplin, J. (1963) Wing base structure in Lepidoptera. 1. Fore wing base. Canadian Entomologist, 95, 1024-1050.

Sorenson, M.D. (1999) TreeRot. Boston University, Boston, MA.

Stekolnikov, A.A. \& Zolotukhin, V.V. (2002) Phylogenetic relationships and systematic position of the family Lemoniidae (Lepidoptera) with account of skeleton structure and muscles of male genitalia. Entomological Review, 82, 680-685.

Sunnucks, P. \& Hales, D.F. (1996) Numerous transposed sequences of mitochondrial cytochrome oxidase I-II in aphids of the genus Sitobion (Hemiptera: Aphididae). Molecular Biology and Evolution, 13, 510-524.

Swinhoe, C. (1892) Catalogue of Eastern and Australian Lepidoptera Heterocera in the collection of the Oxford University Museum. Part 1. Sphinges and Bombyces. Clarendon Press, Oxford.

Swofford, D.L. (2002) PAUP*. Phylogenetic Analysis Using Parsimony (*and Other Methods). Sinauer Associates, Sunderland, MA.

Terauds, A., Williams, M.A., Ireson, J.E., Brieze-Stegeman, R., McQuillan, P.B. \& Leighton, S.M. (1986) Insect pest occurrences in Tasmania, 1984/85. Insect Pest Survey, Vol. 18, pp. [3]+26. Tasmanian Department of Agriculture, Hobart.
Thompson, J.D., Gibson, T.J., Plewniak, F., Jeanmougin, F. \& Higgins, D.G. (1997) The ClustalX windows interface: flexible strategies for multiple sequence alignment aided by quality analysis tools. Nucleic Acids Research, 25, 4876-4882.

Wägele, J.-W. (2001) [Grundlagen der Phylogenetischen Systematik]. Verlag Dr. Friedrich Pfeil, Munich. (English translation 2005: Foundations of Phylogenetic Systematics).

Weller, S.J. \& Pashley, D.P. (1995) In search of butterfly origins. Molecular Phylogenetics and Evolution, 4, 235-246.

Whitfield, J.B. \& Lockhart, P.J. (2007) Deciphering ancient rapid radiations. Trends in Ecology and Evolution, 22, 258-265.

Xia, Q., Zhou, Z., Lu, C. et al. (2004) A draft sequence for the genome of the domesticated silkworm (Bombyx mori). Science, 306, 1937-1940.

Zwick, A. (2001) Das Chaetosema-artige Sinnesorgan der Lasiocampiden (Insecta, Lepidoptera) - eine neue Autapomorphie? [The chaetosema-like sense organ of the Lasiocampidae (Insecta, Lepidoptera) - a new autapomorphy?]. Diploma thesis, Eberhard-Karls-University, Tübingen, Germany.

Zwick, A. (2006) Phylogenetic analyses and taxonomy of Anthelidae (Lepidoptera). PhD thesis, The Australian National University, Canberra, Australia.

Zwickl, D.J. (2006) Genetic algorithm approaches for the phylogenetic analysis of large biological sequence datasets under the maximum likelihood criterion. $\mathrm{PhD}$ thesis, The University of Texas, Austin, U.S.A.

Accepted 28 September 2007

Appendix 1. Specimens sampled, voucher number, GenBank accession numbers and specimen origin.

\begin{tabular}{|c|c|c|c|c|}
\hline \multirow[b]{2}{*}{ Classification } & \multirow[b]{2}{*}{ Voucher no. } & \multicolumn{2}{|c|}{ GenBank accession nos } & \multirow[b]{2}{*}{ Specimen origin } \\
\hline & & CAD & $\mathrm{EF}-1 \alpha$ & \\
\hline \multicolumn{5}{|l|}{ BOMBYCOIDEA } \\
\hline \multicolumn{5}{|l|}{ Anthelidae [ANT] } \\
\hline \multicolumn{5}{|l|}{ Anthelinae } \\
\hline Anthela acuta (Walker, 1855) group & DNA/AZ 019 & EF654588 & EF654554 & AUS, NSW, Budawang NP \\
\hline Anthela addita (Walker, 1865) group & DNA/AZ 001 & EF654589 & EF654542 & AUS, NSW, Tallaganda SF \\
\hline Anthela adriana (Swinhoe, 1902) & DNA/AZ 151 & EF654590 & EF654567 & AUS, WA, Karijini NP \\
\hline Anthela astata Turner, 1926 & DNA/AZ 051 & EF654591 & EF654552 & AUS, QLD, Daintree NP \\
\hline Anthela asterias (Meyrick, 1891) & DNA/AZ 045 & EF654592 & EF654559 & AUS, NSW, Byrock \\
\hline Anthela callixantha (Lower, 1902) & DNA/AZ 153 & EF654593 & EF654556 & AUS, WA, Millstream-Chichester NP \\
\hline Anthela clementi (Swinhoe, 1902) & DNA/AZ 127 & EF654594 & EF654560 & AUS, WA, Karijini NP \\
\hline Anthela cnecias Turner, 1921 & DNA/AZ 004 & EF654595 & EF654563 & AUS, NSW, Badja Swamp NR \\
\hline Anthela euryphrica Turner, 1936 & DNA/AZ 156 & EF654596 & EF654557 & AUS, NSW, Orange \\
\hline Anthela excellens (Walker, 1855) & DNA/AZ 016 & EF654597 & EF654549 & AUS, NSW, Royal NP \\
\hline Anthela ferruginosa (Walker, 1855) & DNA/AZ 154 & EF654598 & EF654544 & AUS, NSW, Budderoo NP \\
\hline Anthela nicothoe (Boisduval, 1832) & DNA/AZ 029 & EF654599 & EF654548 & AUS, ACT, Namadgi NP \\
\hline Anthela ocellata (Walker, 1855) & DNA/AZ 027 & EF654600 & EF654564 & AUS, ACT, Canberra \\
\hline Anthela phoenicias Turner, 1902 & DNA/AZ 068 & EF654601 & EF654566 & AUS, QLD, Carnarvon NP \\
\hline Anthela repleta (Walker, 1855) & DNA/AZ 057 & EF654602 & EF654555 & AUS, QLD, Carnarvon NP \\
\hline Anthela rubicunda (Swinhoe, 1902) & DNA/AZ 120 & EF654603 & EF654561 & AUS, WA, Karijini NP \\
\hline
\end{tabular}


Appendix 1. Continued

\begin{tabular}{|c|c|c|c|c|}
\hline \multirow[b]{2}{*}{ Classification } & \multirow[b]{2}{*}{ Voucher no. } & \multicolumn{2}{|c|}{ GenBank accession nos } & \multirow[b]{2}{*}{ Specimen origin } \\
\hline & & CAD & $\mathrm{EF}-1 \alpha$ & \\
\hline Anthela stygiana (Butler, 1882) & DNA/AZ 035 & EF654604 & EF654550 & AUS, QLD, Tregole NP \\
\hline Anthela tetraphrica Turner, 1921 & DNA/AZ 150 & EF654605 & EF654562 & $\begin{array}{l}\text { AUS, WA, Fortescue River Basin near } \\
\text { Auski roadhouse }\end{array}$ \\
\hline Anthela unisigna Swinhoe, 1903 & DNA/AZ 152 & EF654606 & EF654551 & AUS, WA, Millstream-Chichester NP \\
\hline Anthela varia (Walker, 1855) & DNA/AZ 149 & EF654607 & EF654553 & AUS, ACT, Canberra \\
\hline Anthela virescens Turner, 1939 & DNA/AZ 070 & EF654608 & EF654543 & AUS, QLD, Main Range NP \\
\hline Anthelinae Turner, 1904 sp. n. & DNA/AZ 038 & EF654609 & EF654569 & AUS, QLD, Ravenshoe SF \\
\hline Chelepteryx chalepteryx (R. Felder, 1874) & DNA/AZ 080 & EF654616 & EF654545 & AUS, QLD, Main Range NP \\
\hline Chelepteryx collesi Gray, 1835 ('1834’) & DNA/AZ 162 & EF654617 & {$[\mathrm{N} / \mathrm{A}]$} & AUS, ACT, Canberra \\
\hline Chenuala heliaspis (Meyrick, 1891) & DNA/AZ 028 & EF654618 & EF654568 & AUS, ACT, Namadgi NP \\
\hline Nataxa flavescens (Walker, 1855) & DNA/AZ 024 & EF654635 & EF654547 & AUS, ACT, Namadgi NP \\
\hline Omphaliodes obscura (Walker, 1855) & DNA/AZ 025 & EF654639 & EF654558 & AUS, NSW, Byrock \\
\hline Pseudodreata Bethune-Baker, 1904 sp. & DNA/AZ 199 & EF654642 & EF654546 & PAPUA N.G., Templetons Crossing \\
\hline Pterolocera Walker, 1855 sp. & DNA/AZ 015 & EF654643 & EF654565 & AUS, ACT, Canberra \\
\hline \multicolumn{5}{|l|}{ Munychryiinae } \\
\hline Gephyroneura cosmia Turner, 1921 & DNA/AZ 040 & EF654629 & EF654572 & AUS, QLD, Herberton, Baldy SF \\
\hline $\begin{array}{l}\text { Munychryia periclyta Common \& } \\
\text { McFarland, } 1970\end{array}$ & DNA/AZ 158 & EF654633 & EF654571 & AUS, WA, Cape Arid NP \\
\hline Munychryia senicula Walker, 1865 & DNA/AZ 052 & EF654634 & EF654570 & AUS, QLD, Herberton \\
\hline \multicolumn{5}{|l|}{ Lasiocampidae [LAS] } \\
\hline \multicolumn{5}{|l|}{ Lasiocampinae } \\
\hline \multicolumn{5}{|l|}{ Macromphaliinae } \\
\hline Tolype austella Franclemont, 1973 & DNA/AZ 160 & EF654646 & EF654584 & $\begin{array}{l}\text { U.S.A., AZ, Santa Cruz Co, Pena Blanca } \\
\text { Cyn, Atascosa highlands }\end{array}$ \\
\hline \multicolumn{5}{|l|}{ Chionopsychinae } \\
\hline $\begin{array}{l}\text { Chionopsyche montana Aurivillius, } 1909 \\
\text { Mimallonidae [MIM] }\end{array}$ & DNA/AZ 100 & EF654619 & EF654582 & KENYA, Kibwezi, Umani Springs Camp \\
\hline $\begin{array}{l}\text { Lacosoma chiridota Grote, } 1864 \\
\text { Bombycidae }[\mathrm{BOM}]\end{array}$ & DNA/AZ 204 & EF654632 & {$[\mathrm{N} / \mathrm{A}]$} & U.S.A., FL, Goethe SF \\
\hline \multicolumn{5}{|l|}{ Bombycinae } \\
\hline Bombyx mori (Linnaeus, 1758) & & $\begin{array}{l}\text { AADK } \\
01012397 \\
\text { Xia et al. } \\
(2004)\end{array}$ & $\begin{array}{l}\text { NM } \\
001044045 \\
\text { Kamiie et al. } \\
(1993)\end{array}$ & \\
\hline Gastridiota adoxima (Turner, 1902) & DNA/AZ 202 & EF654627 & {$[\mathrm{N} / \mathrm{A}]$} & AUS, QLD, \\
\hline Ocinara sp. n. Walker, 1856 & DNA/AZ 176 & EF654637 & {$[\mathrm{N} / \mathrm{A}]$} & PHILIPPINES, Palawan, Bataraza \\
\hline \multicolumn{5}{|l|}{ Apatelodinae [APA] } \\
\hline Apatelodes pudefacta Dyar, 1904 & DNA/AZ 159 & EF654610 & EF654580 & U.S.A., AZ, Pima Co, Santa Rita Mtns \\
\hline Olceclostera indistincta (Hy. Edwards, 1886) & DNA/AZ 203 & EF654638 & {$[\mathrm{N} / \mathrm{A}]$} & U.S.A., FL, Goethe SF \\
\hline \multicolumn{5}{|l|}{ Brahmaeidae [BRA] } \\
\hline Acanthobrahmaea europaea (Hartig, 1963) & & {$[\mathrm{N} / \mathrm{A}]$} & $\begin{array}{l}\text { AF234558 } \\
\text { Regier et al. } \\
(2001)\end{array}$ & [ITALY] \\
\hline Brahmaea tancrei Austaut, 1896 & DNA/AZ 191 & EF654614 & $\begin{array}{l}\text { AF234560 } \\
\text { [as B. certhia] } \\
\text { Regier } \text { et al. } \\
\text { (2001) }\end{array}$ & [bred; origin unknown] \\
\hline $\begin{array}{l}\text { Dactyloceras widenmanni } \\
\text { (Karsch, 1895) group }\end{array}$ & DNA/AZ 132 & EF654621 & EF654579 & KENYA, Oloitokitok \\
\hline \multicolumn{5}{|l|}{ Carthaeidae [CAR] } \\
\hline $\begin{array}{l}\text { Carthaea saturnioides Walker, } 1858 \\
\text { Endromidae [END] }\end{array}$ & DNA/AZ 184 & EF654615 & EF654573 & AUS, WA, Cape Arid NP \\
\hline Endromis versicolora (Linnaeus, 1758) & DNA/AZ 187 & EF654624 & $\begin{array}{l}\text { AF234566 } \\
\text { Regier et al. } \\
(2001)\end{array}$ & CZECHIA \\
\hline
\end{tabular}


Appendix 1. Continued

\begin{tabular}{|c|c|c|c|c|}
\hline \multirow[b]{2}{*}{ Classification } & \multirow[b]{2}{*}{ Voucher no. } & \multicolumn{2}{|c|}{ GenBank accession nos } & \multirow[b]{2}{*}{ Specimen origin } \\
\hline & & CAD & $\mathrm{EF}-1 \alpha$ & \\
\hline \multicolumn{5}{|l|}{ Eupterotidae [EUP] } \\
\hline \multicolumn{5}{|l|}{ Eupterotinae } \\
\hline Cotana serranotata (T.P. Lucas, 1894) & DNA/AZ 058 & EF654620 & EF654574 & AUS, QLD, Davies Ck NP \\
\hline Eupterote pallida (Walker, 1855) group & DNA/AZ 167 & EF654625 & {$[\mathrm{N} / \mathrm{A}]$} & PHILIPPINES, Palawan, Bataraza \\
\hline \multicolumn{5}{|l|}{ Panacelinae } \\
\hline Panacela lewinae (Lewin, 1805) & DNA/AZ 069 & EF654641 & EF654575 & AUS, QLD, Mooloolah River NP \\
\hline \multicolumn{5}{|l|}{ Striphnopteryginae } \\
\hline Ebbepterote expansa (T.P. Lucas, 1891) & DNA/AZ 196 & EF654623 & EF654576 & AUS, QLD, Atherton \\
\hline \multicolumn{5}{|l|}{ Janinae } \\
\hline $\begin{array}{l}\text { Hoplojana rhodoptera } \\
\text { (Gerstäcker, 1871) group }\end{array}$ & DNA/AZ 144 & EF654631 & EF654577 & KENYA, Kibwezi, Umani Springs Camp \\
\hline \multicolumn{5}{|l|}{ 'Ganisa group' } \\
\hline Ganisa plana Walker, 1855 & DNA/AZ 168 & EF654626 & {$[\mathrm{N} / \mathrm{A}]$} & PHILIPPINES, Palawan, Bataraza \\
\hline \multicolumn{5}{|l|}{ Lemoniidae [LEM] } \\
\hline Lemonia dumi (Linnaeus, 1761) & & {$[\mathrm{N} / \mathrm{A}]$} & $\begin{array}{l}\text { AF234570 } \\
\text { Regier et al. } \\
(2001)\end{array}$ & \\
\hline Sabalia picarina Walker, 1865 & DNA/AZ 131 & EF654644 & EF654578 & $\begin{array}{l}\text { KENYA, road Tsavo West NP to } \\
\text { Oloitokitok }\end{array}$ \\
\hline \multicolumn{5}{|l|}{ Saturniidae [SAT] } \\
\hline \multicolumn{5}{|l|}{ Saturniinae } \\
\hline Attacus lemairei Peigler, 1985 & DNA/AZ 178 & EF654612 & {$[\mathrm{N} / \mathrm{A}]$} & PHILIPPINES, Palawan, Bataraza \\
\hline Aurivillius Packard, 1902 sp. & DNA/AZ 141 & EF654613 & {$[\mathrm{N} / \mathrm{A}]$} & KENYA, Kibwezi, Umani Springs Camp \\
\hline Goodia kuntzei (Dewitz, 1881) & DNA/AZ 146 & EF654630 & {$[\mathrm{N} / \mathrm{A}]$} & KENYA, Kibwezi, Umani Springs Camp \\
\hline Opodiphthera eucalypti Scott, 1864 & DNA/AZ 008 & EF654640 & $\begin{array}{l}\text { AF373938 } \\
\text { Regier } \\
\text { et al. } \\
(2002)\end{array}$ & AUS, NSW, Tallaganda SF \\
\hline Usta angulata Rothschild, 1895 & DNA/AZ 136 & EF654647 & {$[\mathrm{N} / \mathrm{A}]$} & KENYA, Kibwezi, Umani Springs Camp \\
\hline \multicolumn{5}{|l|}{ Agliinae } \\
\hline Aglia tau Linnaeus, 1758 & DNA/AZ 186 & EF654586 & EF654540 & AUSTRIA \\
\hline \multicolumn{5}{|l|}{ Arsenurinae } \\
\hline Arsenura armida (Cramer, 1779) & DNA/AZ 189 & EF654611 & EF654541 & VENEZUELA \\
\hline \multicolumn{5}{|l|}{ Sphingidae $[\mathrm{SPH}]$} \\
\hline \multicolumn{5}{|l|}{ Sphinginae } \\
\hline Acherontia styx (Westwood, 1847) & DNA/AZ 163 & EF654585 & {$[\mathrm{N} / \mathrm{A}]$} & PHILIPPINES, Palawan, Bataraza \\
\hline Agrius godarti (W.S. Macleay, 1826) & DNA/AZ 054 & EF654587 & {$[\mathrm{N} / \mathrm{A}]$} & AUS, QLD, Emerald \\
\hline \multicolumn{5}{|l|}{ Smerinthinae } \\
\hline Daphnusa ocellaris Walker, 1856 & DNA/AZ 177 & EF654622 & {$[\mathrm{N} / \mathrm{A}]$} & PHILIPPINES, Palawan, Bataraza \\
\hline Smerinthus ocellata (Linnaeus, 1758) & DNA/AZ 188 & EF654645 & EF654583 & GERMANY \\
\hline \multicolumn{5}{|l|}{ NOCTUOIDEA } \\
\hline \multicolumn{5}{|l|}{ Notodontidae [NOT] } \\
\hline $\begin{array}{l}\text { Thaumetopoeinae } \\
\text { Ochrogaster lunifer Herrich-Schäffer, } 1855 \\
\text { ('1850-1869') }\end{array}$ & DNA/AZ 048 & EF654636 & EF654581 & AUS, NSW, Cocoparra NP \\
\hline
\end{tabular}

AUS, AUSTRALIA; NP, National Park; NR, Nature Reserve; SF, State Forest. 